\title{
Testing for delayed mortality effects in the early marine life history of Columbia River Basin yearling Chinook salmon
}

\author{
Erin L. Rechisky ${ }^{1, *}$, David W. Welch ${ }^{1}$, Aswea D. Porter ${ }^{1}$, Jon E. Hess ${ }^{2}$, \\ Shawn R. Narum ${ }^{2}$
}

${ }^{1}$ Kintama Research Services, Nanaimo, British Columbia V9S 3B3, Canada

${ }^{2}$ Columbia River Inter-Tribal Fish Commission, Hagerman, Idaho 83332, USA

\begin{abstract}
Juvenile Snake River Chinook salmon Oncorhynchus tshawytscha pass through 8 major hydroelectric dams during their $>700 \mathrm{~km}$ migration to the sea, or are transported downriver to avoid these dams. Both of these anthropogenic processes may decrease fitness and lead to delayed mortality in the estuary and coastal ocean, and thus reduce the rate at which adults return to spawn. Using a large-scale telemetry array, we tested whether there was support for (1) hydrosysteminduced delayed mortality (hydro-DM) of yearlings migrating from the Snake River relative to yearlings migrating from the mid-Columbia River, and (2) transportation-induced delayed mortality (transport-DM) for transported Snake River yearlings relative to yearlings which migrated in-river. We also tested for differential early marine survival between yearlings migrating from the Snake and upper Columbia Rivers. In 2010, seaward migrating yearling Chinook were captured at dam bypasses and origin was based on capture location; in 2011, dam-caught fish were identified using genetic stock identification. Survival of all groups during the initial $750 \mathrm{~km},>1 \mathrm{mo}$ long migration through the estuary and coastal ocean to northwestern Vancouver Island ranged between 14 and $19 \%$ in 2010 and was lower in 2011 (1.5-8\%). We found no support for hydro-DM, as survival of inriver migrating Snake and mid-Columbia River yearlings was indistinguishable. We found mixed results for our transportation study, with no support for transport-DM in 2010, and weak support in 2011. Our study provides further evidence that freshwater management strategies may not increase the rate of Chinook salmon returning to the Snake River if prior freshwater experience has no substantial influence on subsequent survival in the ocean.
\end{abstract}

KEY WORDS: Oncorhynchus tshawytscha - Latent mortality - Transportation - Snake River • Early marine survival · Acoustic telemetry

\section{INTRODUCTION}

The Columbia River Basin (Fig. 1) once boasted some of the largest runs of Chinook salmon Oncorhynchus tshawytscha in the Pacific Northwest of North America. Chapman (1986) estimated that 2.7 million spring/summer Chinook salmon returned to the Basin annually in the late 19th century. The cumulative impacts of over-harvesting (Chapman 1986, Ward et al. 1997), hydroelectric dam development

*Corresponding author: erin.rechisky@kintama.com

$\S_{\text {Corrections were made after publication. For details see }}$ www.int-res.com/articles/meps_oa/m597p273.pdf This corrected version: June 11, 2018
(Raymond 1979, 1988, Schaller et al. 1999), habitat degradation (Paulsen \& Fisher 2001), hatchery production (National Research Council 1996, Levin et al. 2001) and unfavourable ocean climate (Mantua et al. 1997, Hare et al. 1999) reduced return rates to fewer than 100000 fish by the end of the 20th century (Joint Columbia River Management Staff 2012). During the 1990s, Snake River (a tributary of the Columbia River) spring/summer Chinook were listed as threatened, and upper Columbia River spring Chinook were listed 


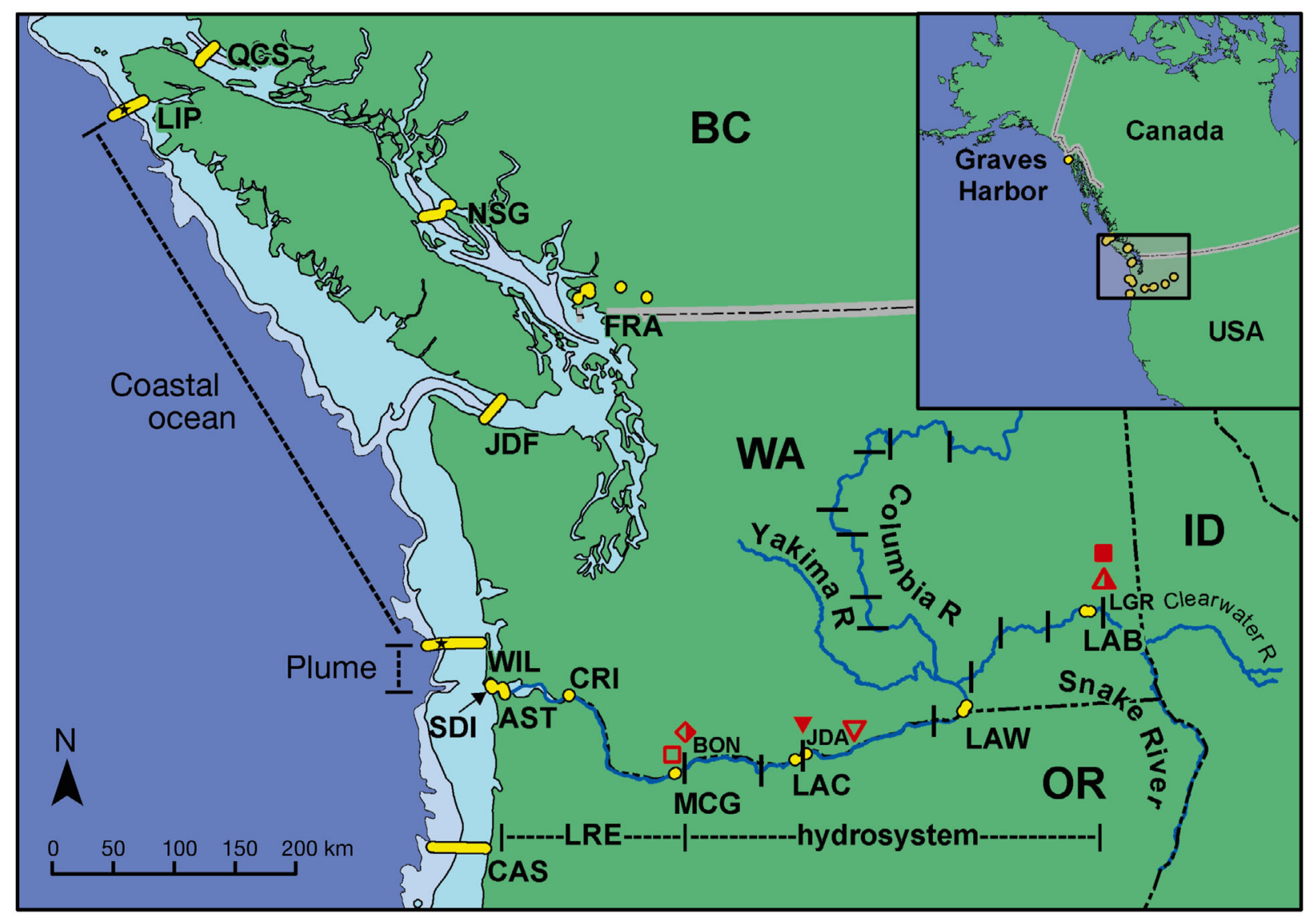

Fig. 1. Study area with acoustic tracking array (yellow dots and lines), capture and release locations (red symbols) and habitat designations (short-dashed lines, LRE: lower Columbia River and estuary). Snake and Columbia River dams are indicated with black vertical and horizontal lines. In 2010, Snake in-river (SIR) migrating salmon smolts were collected and released at Lower Granite Dam (LGR; half-filled red triangle), and Columbia in-river (CIR) smolts were collected at John Day Dam (JDA; inverted filled red triangle) and released $42 \mathrm{~km}$ upstream of JDA (inverted open red triangle). In 2011, all in-river smolts were collected and released at Bonneville Dam (BON; half-filled red diamond). In both years, Snake River transported (STR) smolts were collected at LGR (filled red square) and released at BON (open red square). In 2010, river and LRE sub-arrays were deployed at Lake Bryan (LAB), Lake Wallula (LAW), Lake Celilo (LAC), McGowans Channel (MCG), Crims Island (CRI), Astoria (AST) and Sand Island (SDI). Marine sub-arrays were deployed at Willapa Bay, WA (WIL), Lippy Point, BC (LIP), and Graves Harbor, AK, and extended across the continental shelf out to approximately the 200 isobath (indicated by the star). In 2011, LAB, LAW and LAC were removed since all smolts were released at BON. The CRI and Graves Harbor sub-arrays were also removed, and the WIL and LIP sub-arrays were extended offshore to the $500 \mathrm{~m}$ isobath. The Cascade Head, OR (CAS), subarray was deployed in 2011 and extended out to the $500 \mathrm{~m}$ isobath. No smolts were detected on the Fraser River (FRA) subarrays or on the Pacific Ocean Shelf Tracking (POST) sub-arrays in Juan de Fuca Strait (JDF), Northern Strait of Georgia (NSG) and Queen Charlotte Strait (QCS). Isobaths show the continental shelf edge at 200 and $500 \mathrm{~m}$ depth

as endangered under the US Endangered Species Act (ESA); however, mid-Columbia River spring Chinook have not warranted ESA listing (Fig. S1 in the Supplement at www.int-res.com/articles/suppl/m496p159_ suppl.pdf). A combination of unprecedented mitigation efforts within the Columbia River basin and improved ocean conditions have increased Chinook survival during the last decade (Williams et al. 2005), but the number of fish returning still remains at about $10 \%$ of the historical estimate (Joint Columbia River Management Staff 2012).
Columbia and Snake River dams altered the landscape from a free-flowing river to a series of slowflowing reservoirs which resulted in fish habitat loss, proliferation of non-indigenous aquatic species and altered salmon migration routes and speeds (National Research Council 1996). Although dam bypasses are available to seaward migrating smolts, and water is spilled over the dams to promote fish passage, the cumulative effect of dams (dam passage and slower movement rate in reservoirs) is thought to lead to increased stress and decreased fitness for fish originat- 
ing from the Snake River Basin (Budy et al. 2002). For various reasons, upper Columbia River dams have not been the subject of as much criticism (National Research Council 1996). Smolt-to-adult return rates (SARs) of the aggregate wild Snake River spring Chinook salmon run averaged only $1.1 \%$ over the last decade (Tuomikoski et al. 2012), well below the recovery target of $4 \%$ and minimum target of $2 \%$ (Northwest Power and Conservation Council 2009). In contrast, the SARs of wild spring Chinook salmon from 2 mid-Columbia River tributaries (John Day and Yakima Rivers) were 4.3 and $3.1 \%$, respectively, over the same time period (Tuomikoski et al. 2012). Populations from the mid-Columbia migrate through only the lower Columbia River dams and are not exposed to Snake River dam passage. Thus, the lower productivity of the Snake River population was attributed to their exposure to first the 4 lower Snake River dams in addition to the 4 lower Columbia River dams which make up the Federal Columbia River Hydropower System (FCRPS or 'hydrosystem'; Fig. 1; Schaller et al. 1999, Deriso et al. 2001, Wilson 2003).

To avoid stressors associated with migration through the hydrosystem, some smolts are diverted from the Snake River dam bypasses into barges and transported $460 \mathrm{~km}$ downstream to below Bonneville Dam in the lower Columbia River (Fig. 1), the last (lowest) dam in the hydrosystem. Since survival of spring Chinook smolts after approximately 2 to $3 \mathrm{wk}$ of migration in the hydrosystem is $\sim 50 \%$ (Faulkner et al. 2011), and survival during the $\sim 36 \mathrm{~h}$ trip in the barge is nearly $100 \%$ (McMichael et al. 2011), transported smolts initially survive at twice the rate of inriver migrants. However, transportation has not reliably doubled the rate of adults returning from the ocean, and in some years transported smolts returned at lower rates than in-river migrants, indicating that the transportation program may have reduced adult return rates of spring Chinook salmon (Ward et al. 1997, Williams et al. 2005). Since the mid-1990s, the SAR of transported wild spring Chinook smolts averaged only 1.2 times that of the in-river migrants $(90 \%$ $\mathrm{CI}=0.93-1.57$ ), indicating only a small benefit from transportation on average (Tuomikoski et al. 2012).

The concept of delayed mortality was introduced because direct dam-related mortality, which has been relatively stable for decades, and barge-related mortality could not explain the magnitude of poor Snake River Chinook adult returns (Williams et al. 2005). Delayed mortality is thought to occur in either the Columbia River estuary or ocean, and can be hydrosystem-induced (hereafter hydro-DM) or transportation-induced (hereafter transport-DM). Budy et al. (2002) reviewed the potential effect of stressors that Snake River spring Chinook salmon may encounter during their downstream migration (e.g. injury, trauma, energy depletion, increased predation and disease susceptibility) and concluded that the accumulation of multiple stressors results in hydro-DM in the estuary and coastal ocean. Haeseker et al. (2012) provided further evidence for hydroDM by demonstrating that freshwater and ocean survival is correlated, and concluded that increased spill and decreased transit time in the hydrosystem improved survival in both environments.

Anderson et al. (2011) reviewed the numerous potential causes of transport-DM, including physiological or behavioural stress associated with dam bypass facilities (Budy et al. 2002), co-transportation with steelhead salmon Oncorhynchus mykiss (Congleton et al. 2000), increased disease transmission (Van Gaest et al. 2011), smaller body size and earlier ocean entry of transported smolts (Muir et al. 2006) and impaired adult homing abilities (Keefer et al. 2008). Although there is no consensus on how delayed mortality of transported spring Chinook salmon occurs, timing of transport appears to be important (Muir et al. 2006, Smith et al. 2013). As a result, managers have delayed the start of the transportation program by several weeks in recent years (Tuomikoski et al. 2012).

As spring/summer Chinook salmon typically spend 2 yr at sea, and conservation efforts and technological fixes in the Columbia River Basin have not increased population growth rates to sustainable levels, the marine phase has been given increasing attention. Modelling exercises have demonstrated that even if hydrosystem survival was $100 \%$, population growth rates would continue to decline unless reductions in first-year mortality, particularly early ocean and estuarine mortality, occurred (Kareiva et al. 2000). Several studies have shown that survival of spring Chinook is high in the Columbia River estuary (Schreck et al. 2006, Clemens et al. 2009, McMichael et al. 2010, Harnish et al. 2012, Rechisky et al. 2012, 2013), leaving little room for improvement. Given the significant correlation between ocean conditions that juvenile spring Chinook salmon encounter following ocean entry and the number of adults subsequently returning to the Columbia River (Burke et al. 2013, NOAA Fisheries Service 2013) and that depressed Chinook salmon populations are not unique to the Columbia River Basin (Chinook salmon in the highly altered Sacramento River suffered a recent collapse, Lindley et al. 2009, as did several populations originating from pristine Alaskan rivers, ADF\&G Chinook Salmon Research Team 2013), increasing scrutiny of marine survival is warranted. 
Although delayed mortality is assumed to manifest soon after ocean entry, previous evaluation of hydroor transport-DM has been based on studies where fish were tagged as juveniles and then captured or detected as returning adults (e.g. Muir et al. 2006, Schaller \& Petrosky 2007, Haeseker et al. 2012). These studies confound delayed mortality in the early marine environment with events influencing survival that occur later in the marine life history. The only way to unambiguously determine the magnitude of early marine mortality and any potential relationship to prior freshwater experience is to estimate the survival of tagged juveniles directly in the estuary and early marine phase (e.g. Rechisky et al. 2013).

Using a continental-scale acoustic telemetry array (Fig. 1), we tracked the movements and estimated survival to northern Vancouver Island (a distance of $750 \mathrm{~km}$ beyond the final dam) of both in-river migrating and transported yearling Chinook salmon smolts obtained from dam bypass facilities in the Columbia and Snake Rivers in 2010 and 2011. To evaluate hydro-DM, we compared the survival estimates of inriver migrating Snake River yearling Chinook (SIR) to in-river migrating mid-Columbia River yearling Chinook (MCIR). In 2010, the sample of smolts captured in the Columbia River (CIR) was comprised of an unknown proportion of Snake, mid- and upper Columbia smolts which precluded us from specifically testing the hydro-DM hypothesis in that year. In 2011, we used genetic stock analyses to determine smolt origin, and thus we could directly test the hydro-DM hypothesis. We also had the unique opportunity in 2011 to compare survival of endangered upper Columbia yearling Chinook salmon (UCIR), which may migrate through as many as 9 dams before reaching the lower river and estuary, to SIR salmon in the estuary and coastal ocean. For completeness, we report survival results from the Columbia/Snake comparison in 2010 as supporting information.

To evaluate transport-DM, we compared survival estimates of the SIR treatment type to Snake River yearling Chinook transported (STR) via barge to below Bonneville Dam. The origin of SIR and STR smolts was known in both years.

In this study, we report findings from the final $2 \mathrm{yr}$ of a 6 yr study. We (E.L.R., D.W.W., A.D.P.) began testing hydro- and transport-DM in 2006 using Spring Chinook smolts obtained directly from a Snake River Basin hatchery (Dworshak). Each treatment (in-river and transport) had 2 release groups, and releasetiming was manipulated so that ocean-entry timing was similar for the treatment groups as well as for tagged smolts obtained from a mid-Columbia River hatchery. We found no evidence of hydro- (Rechisky et al. 2009, 2013) or transport-DM (Rechisky et al. 2012) from 2006 to 2009. In 2010 and 2011, we collected Chinook smolts (which were primarily hatchery origin) from dam bypass facilities and released them over a broader interval. Results from the current study are thus more reflective of the general population of hatchery smolts migrating through the Columbia River Basin. If survival differences arise in the estuary and coastal ocean for the various in-river treatment types as a result of the degree of dam passage, as postulated, we should expect survival to reflect the degree of ESA listing, i.e. $\mathrm{S}_{\mathrm{MCIR}}>\mathrm{S}_{\mathrm{SIR}}>$ $\mathrm{S}_{\mathrm{UCIR}}$. If transportation further reduces survival of yearling Chinook originating from the Snake River, then we should expect transported fish to have lower survival than their in-river counterparts, i.e. $\mathrm{S}_{\mathrm{SIR}}>\mathrm{S}_{\mathrm{STR}}$.

\section{MATERIALS AND METHODS}

\section{Species run and rearing type}

Chinook salmon in the interior Columbia River Basin (upstream of Bonneville Dam) exhibit 2 life history strategies that belong to separate major genetic lineages (e.g. Narum et al. 2010). Although this is an oversimplification, these lineages are commonly differentiated by a suite of traits including spawning location, adult upstream run timing and marine distribution. Chinook that return to their natal rivers in the spring and early summer ('spring' or 'spring/summer' Chinook) generally spawn in headwater tributaries in late summer and fall, 4 to 6 mo after river entry. Their offspring, which then spend more than $1 \mathrm{yr}$ in fresh water before migrating seaward to coastal waters in the spring, are also referred to as 'stream-type'. Spring Chinook smolts then migrate northward along the continental shelf after ocean entry and then eventually are distributed through the oceanic subarctic Pacific Ocean. Chinook that enter fresh water in the summer and fall ('fall' Chinook) spawn in mainstem locations shortly after entry, and their offspring are considered 'ocean-type' because they migrate to the ocean the following summer as subyearlings (Healey 1991). In the marine environment, fall Chinook are typically found closer to shore and seem to remain as continental shelf residents for their entire marine phase.

In this study we collected and tagged migrating, yearling ( $>1 \mathrm{yr}$ old) Chinook salmon smolts in the spring at Columbia River Basin dams; thus, salmon 
Table 1. Oncorhynchus tshawytscha. Attributes of tagged, yearling Chinook smolts. All smolts were implanted with both acoustic and passive integrated transponder (PIT) tags. FL: fork length; LGR: Lower Granite Dam; JDA: John Day Dam; BON: Bonneville Dam; SIR: Snake in-river; CIR: Columbia in-river; STR: Snake transport; MCIR: mid-Columbia in-river; UCIR: upper Columbia in-river; PBT: parentage based tagging; GSI: genetic stock identification. \% hatchery origin was determined by the absence of an adipose fin supplemented by genetic stock analysis for SIR and STR in 2011 (see 'Materials and methods'). Tag burden was calculated as tag mass in air divided by fish mass in air

\begin{tabular}{|c|c|c|c|c|c|c|c|}
\hline $\begin{array}{l}\text { Collection } \\
\text { site }\end{array}$ & $\begin{array}{l}\text { Treat- } \\
\text { ment } \\
\text { type }\end{array}$ & Stock ID & $\begin{array}{l}\text { Method used } \\
\text { to determine } \\
\text { stock }\end{array}$ & $\mathrm{n}$ & $\begin{array}{c}\% \\
\text { hatchery } \\
\text { origin }\end{array}$ & $\begin{array}{l}\text { Mean FL (range) } \\
(\mathrm{mm})\end{array}$ & $\begin{array}{c}\text { Mean \% tag } \\
\text { burden } \\
\text { (range) }\end{array}$ \\
\hline \multicolumn{8}{|l|}{2010} \\
\hline LGR & SIR & Snake River & Collection site & 383 & 97 & $141.6(130-167)^{\mathrm{b}}$ & $5.5(3.2-8.0)$ \\
\hline JDA & CIR & Columbia River ${ }^{a}$ & Collection site & 790 & 62 & $161.3(130-215)^{\mathrm{C}}$ & $3.7(1.7-8.0)$ \\
\hline LGR & STR & Snake River & Collection site & 406 & 94 & $141.8(130-171)^{\mathrm{b}}$ & $5.4(2.4-7.8)$ \\
\hline \multicolumn{8}{|l|}{2011} \\
\hline $\mathrm{BON}$ & SIR & Snake River & $\mathrm{PBT}+\mathrm{GSI}$ & 80 & 98 & $147.6(132-168)^{\mathrm{d}}$ & $5.4(3.3-0.4)$ \\
\hline $\mathrm{BON}$ & MCIR & Mid-Columbia River & GSI & 59 & 81 & $144.0(131-168)^{\mathrm{e}}$ & $5.7(3.2-7.7)$ \\
\hline $\mathrm{BON}$ & UCIR & Upper Columbia River & GSI & 386 & 92 & $143.6(130-170)^{\mathrm{e}}$ & $5.5(2.7-7.8)$ \\
\hline LGR & STR & Snake River & $\mathrm{PBT}+$ site & 200 & 99 & $142.3(130-165)^{\mathrm{e}}$ & $5.8(3.5-7.9)$ \\
\hline
\end{tabular}

smolts tagged in our study were primarily the spring/ summer run type which were differentiated from fall run type by their seaward migration timing and larger body size. It is possible, however, that some fall Chinook were included in our 2010 sample, as some of the summer/fall Chinook hatchery programs in the Columbia River (at least above the Snake confluence) release fall Chinook smolts as yearlings. Additionally, a small proportion of fall Chinook smolts have been known to spend an additional winter in freshwater and then migrate seaward as yearlings at approximately the same time as spring Chinook, albeit at a larger body size (Connor et al. 2005). In 2011, we were able to exclude this fall Chinook ecotype from our analysis following stock identification (see Results; $7 \%$ were fall Chinook). For simplicity, we refer to all smolts in our study as yearling Chinook.

\section{Smolt collection sites, release sites and populations studied}

In 2010, we collected migrating yearling Chinook smolts $\geq 130 \mathrm{~mm}$ fork length (FL) from the juvenile fish bypass facilities at Lower Granite Dam on the lower Snake River and at John Day Dam on the lower Columbia River (Fig. 1). Smolts collected at Lower Granite Dam were randomly allocated into Snake inriver (SIR) and Snake transported (STR) treatment groups. The SIR groups were released into the tailrace below Lower Granite Dam over $8 \mathrm{~d}$, with $~ 50$ smolts released per day (range 37-52) between 17
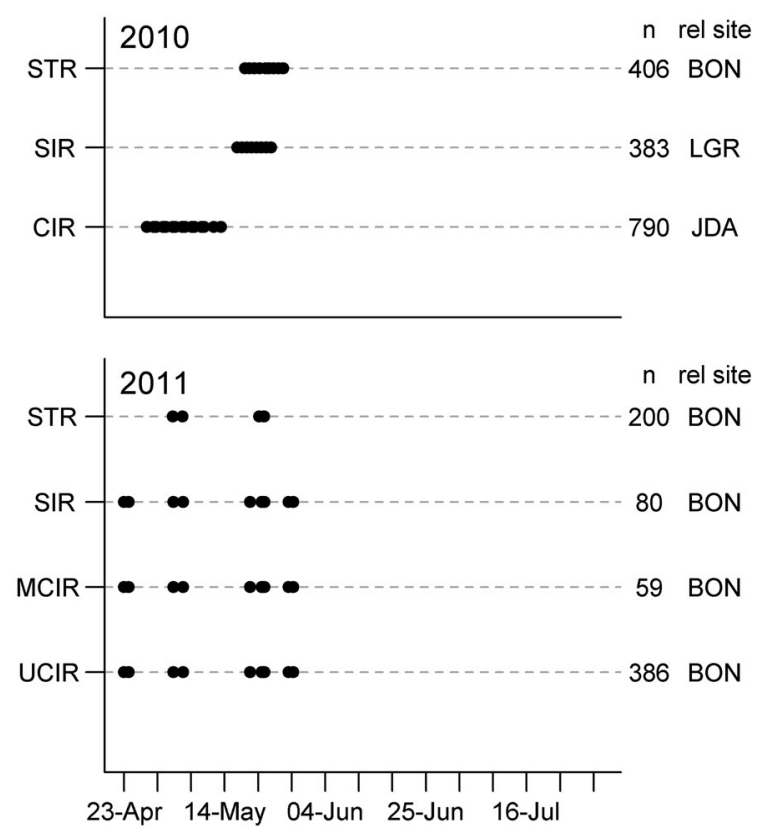

Fig. 2. Oncorhynchus tshawytscha. Release dates for acoustic tagged Columbia River Basin yearling Chinook. STR: Snake transported; SIR: Snake in-river; CIR: Columbia inriver; MCIR: mid-Columbia in-river; UCIR: upper Columbia in-river; rel site: release site (abbreviations defined in Fig. 1)

and 24 May (383 fish in total; Table 1, Fig. 2). Transported smolts were concurrently tagged and then loaded into barges at the dam in groups of $\sim 50$ fish each day (range 22-51) and transported for $\sim 36 \mathrm{~h}$ to a release site below Bonneville Dam in the lower Columbia River (river km 222-225), the last (lowest) 
dam in the hydrosystem. The STR fish were released between 19 and 27 May ( 9 release groups; 406 fish in total). Columbia in-river (CIR) smolts were collected and tagged at John Day Dam and then released $42 \mathrm{~km}$ above the dam in daily groups of $\sim 50$ smolts (range 48-52 except 1 release group that combined $2 \mathrm{~d}$ of tagged smolts, for a total of 98). The CIR fish were released between 28 April and 13 May (15 release groups; 790 fish in total; Table 1, Fig. 2).

Smolts in the CIR group collected at John Day Dam in 2010 originated from the mid-Columbia, upper Columbia and Snake Rivers; however, the proportion of these stocks in our experiment was unknown because we did not identify stock of origin for each individual. Based on the computed estimates of the number of Chinook smolts arriving at John Day Dam in 2010, most of the 2010 yearling Chinook sample were likely of spring run upper Columbia River origin with smaller numbers of spring run mid-Columbia and spring run Snake River origin (Ferguson 2010). This is consistent with genetic analysis of smolts that we collected and tagged at Bonneville Dam in 2011 (67\% upper Columbia spring, $10 \%$ mid-Columbia spring, $14 \%$ Snake spring, 9\% interior-Columbia fall; see 'Results: Stock identification'). Because we could not individually identify fish originating from the mid-Columbia River region in our 2010 sample, we could not explicitly test the hydro-DM hypothesis (survival of SIR relative to MCIR) in that year. We do, however, present a differential survival analysis of the general CIR group collected at John Day Dam relative to the SIR group collected at Lower Granite Dam in 2010, as estuarine and early marine survival of a pure-SIR group is hypothesized to be lower due to Snake River dam passage than for a mixed group containing mostly mid- and upper Columbia River origin smolts.

In 2011, STR smolts were again collected from the juvenile fish bypass facility at Lower Granite Dam on the Snake River. One hundred smolts were tagged, transported, and then released from the barge in 2 intervals, one in early May and another in mid-May (200 fish in total; Table 1, Fig. 2). All in-river migrating groups (SIR, MCIR, UCIR) were collected from the juvenile fish bypass facility at Bonneville Dam. Approximately 100 to 200 fish were tagged and released at each of 4 intervals between 23 April and 28 May (580 fish in total, 525 used in the analysis; Table 1, Fig. 2). There were fewer release intervals of STR fish because the transport season was shorter than the overall migration (Fig. 2). A caudal fin clip was collected from each tagged fish and genetic stock analyses were performed to determine the run type (e.g. spring or fall run), ecotype (e.g. yearling spring or hold over yearling fall), stock of origin (i.e. Snake River, upper Columbia River or mid-Columbia River) and hatchery of origin for Snake River smolts (see 'Results: Stock identification' and Table 1 for final sample size for each stock.). Thus, in 2011, we were able to test hydro-DM for the SIR group relative to the in-river migrating mid-Columbia yearling Chinook (MCIR) group, and to evaluate differential survival for the SIR group relative to endangered upper Columbia in-river populations (UCIR).

The majority of smolts captured were hatchery reared as indicated by the absence of an adipose fin (Table 1). Adipose fin removal is implemented at most hatcheries (e.g. in 2010-2011, 90\% of smolts released in the Snake and Columbia Rivers above Bonneville Dam, and $~ 92 \%$ of smolts released in the Snake River were either adipose fin-clipped or passive integrated transponder [PIT]-tagged; www.FPC. org). In 2010, we assumed that fish with their adipose fin intact were progeny of naturally spawning adults, i.e. 'wild'. In 2011, we supplemented this diagnostic with results from the parentage-based tagging genetic analysis which was applicable to SIR and STR groups only (see 'Stock identification' below).

During the final $2 \mathrm{~d}$ of tagging at Bonneville Dam (in 2011), some tagged smolts were inadvertently exposed to gas-supersaturated river water at the tagging facility, presumably due to high spill levels at up-river dams. This resulted in the death of 20 smolts due to gas bubble trauma (Bouck 1980, Mesa et al. 2000), reducing the total sample size released at Bonneville Dam from 600 to 580 .

\section{Stock identification}

A combination of 2 genetic assignment methods was used to determine the most probable stock of origin for each smolt for which we obtained a caudal fin clip in 2011: (1) genetic stock identification (GSI) and (2) parentage-based tagging (PBT, e.g. Steele et al. 2011). The GSI method employed 188 single nucleotide polymorphism (SNP) loci that were used to genotype individuals from reference populations in the Columbia River Basin. These reference populations were classified into coarse-scale reporting groups and then used to individually assign all tagged smolts to their likely reporting-group-oforigin (see Hess et al. 2012 for details regarding baseline and GSI accuracy). The following 5 coarsescale reporting groups were used to represent the entire Columbia River Basin: lower Columbia River spring and fall-run, middle Columbia River spring- 
2010

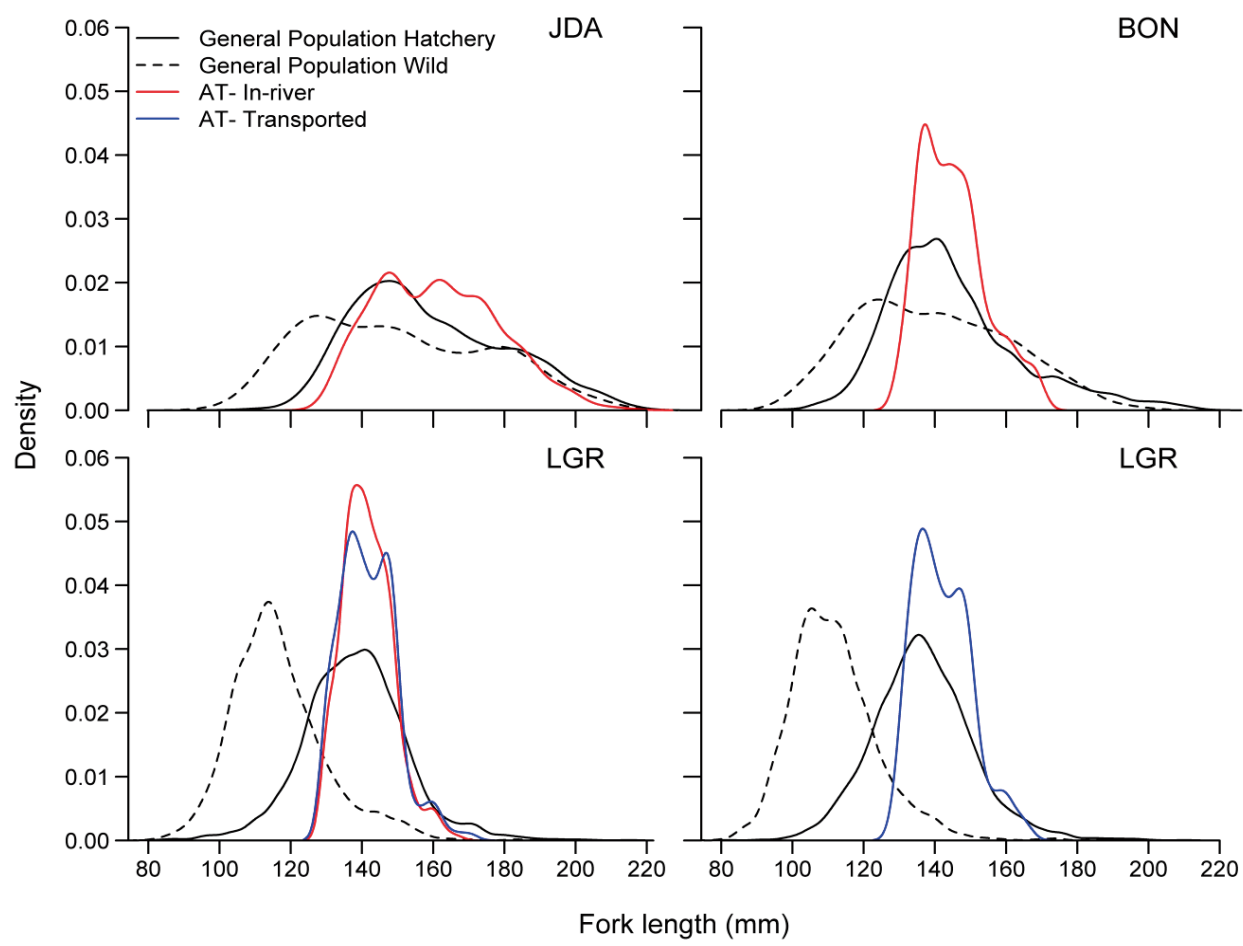

Fig. 3. Oncorhynchus tshawytscha. Fork length of yearling smolts (kernel density estimates). The solid black lines represent the general population of hatchery smolts, and the dashed black lines represent the general population of wild smolts migrating through Lower Granite (LGR), John Day (JDA), and Bonneville (BON) Dams (data provided by the Pacific States Marine Fisheries Commission). Red lines represent in-river groups of acoustic tagged (AT) smolts and blue lines represent AT smolts transported from LGR run, upper Columbia River spring-run, Snake River spring/summer-run and interior Columbia River summer/fall-run. These reporting groups generally correspond to the evolutionarily significant units (ESUs) used by the ESA to designate conservation status (Fig. S1 in the Supplement). ONCOR v1.0 (www.montana.edu/kalinowski/Software/ONCOR. htm) was used to assign individual smolts according to highest probability ('best estimate') baseline reporting groups. These 5 reporting groups were found to yield high assignment accuracy (averaging greater than $85 \%$ correct assignment) according to the leave-1-out test performed in ONCOR v1.0.

The PBT analysis employed a pedigree approach by genotyping 95 SNPs in nearly all (94\%) potential spring/summer Chinook salmon parents spawned at Snake River hatcheries in 2009 in order to assign smolt progeny back to their parents, and thus to their specific hatcheries. Assignments with the PBT approach are nearly $100 \%$ accurate since offspring are matched directly to parents (Steele et al. 2013). We performed all parental assignments using the program SNPPIT (Anderson 2010) and used a false discovery rate threshold of $1 \%$ as a basis for accepting confident assignments. Most Snake River hatchery smolts collected at the Lower Granite and Bonneville Dams could be matched with their parents using PBT. If PBT results were not available (i.e. for natural-origin smolts, or for smolts whose parents were not genotyped), smolts tagged at Lower Granite Dam were assigned to the Snake River spring/summer stock based on collection site (although we confirmed using GSI that no fall Chinook were present in the Lower Granite Dam sample). For smolts that were collected at Bonneville Dam, stock of origin was determined with PBT as a priority due to its high level of accuracy, or determined by GSI as the next best alternative.

\section{Smolt size distribution and migration timing}

In both years, smolts $\geq 130 \mathrm{~mm}$ FL were tagged in order to avoid large tag burdens. This size criterion prevented us from tagging the smallest individuals from the hatchery populations, and the majority of the wild smolts passing Lower Granite Dam (Fig. 3). Both hatchery and wild smolts were larger at John Day and Bonneville Dams. In 2010, the upper $74 \%$ of the size range of the general hatchery population and the upper $15 \%$ of the size range of the wild population sampled at Lower Granite Dam met our size criterion. At John Day Dam the upper $96 \%$ of the hatchery and the upper $74 \%$ of the wild population met our size criterion. In 2011, the upper $71 \%$ of the general hatchery and the upper $8 \%$ of the general wild population at Lower Granite Dam met our size criterion. At Bonneville Dam, the upper $81 \%$ of the hatchery and the upper $63 \%$ of the wild population met our size criterion. 


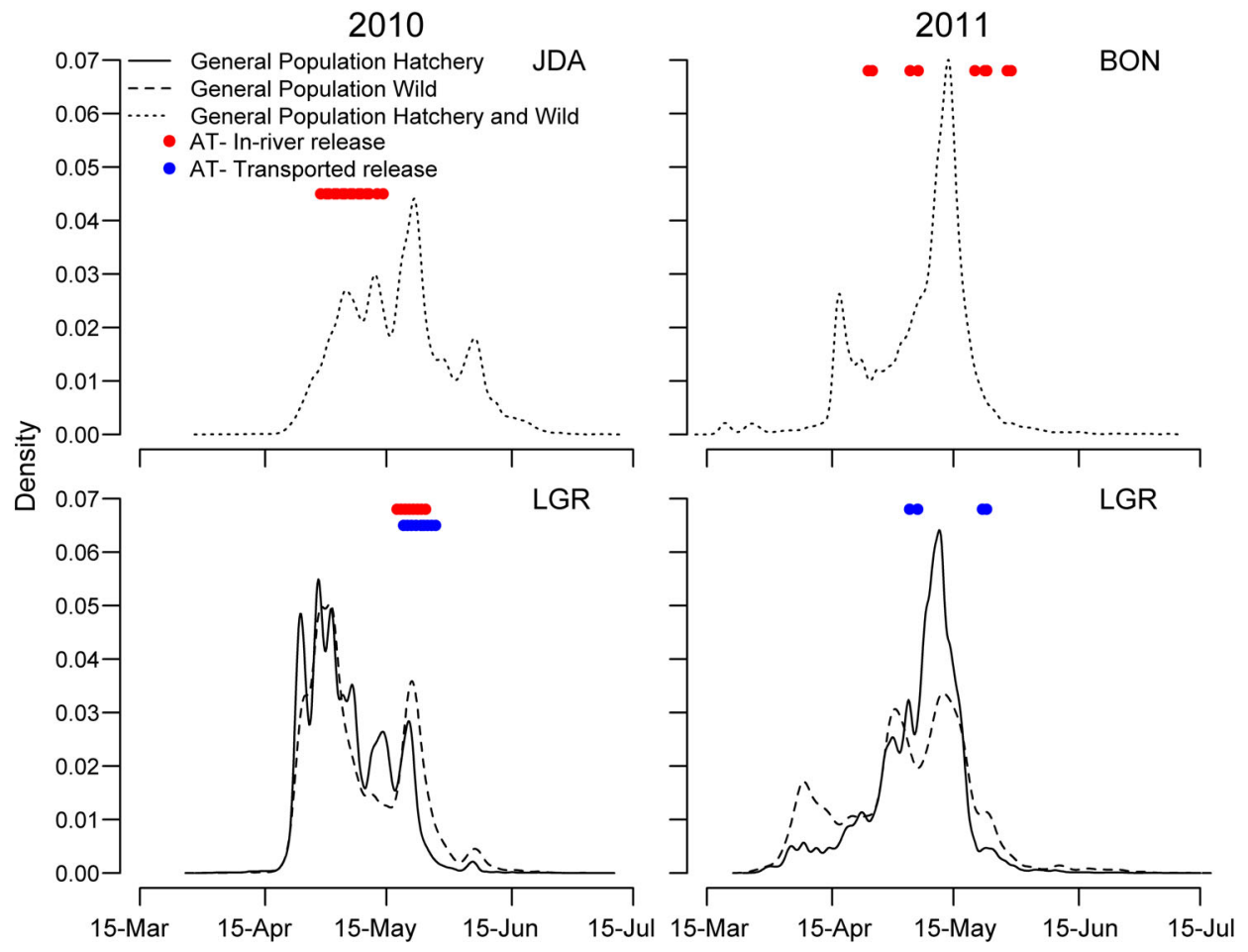

Fig. 4. Oncorhynchus tshawytscha. Run-timing of yearling smolts (kernel density estimates). The dotted black lines represent the general population of hatchery and wild smolts combined migrating through John Day (JDA) and Bonneville (BON) Dams. The solid and dashed black lines represent the general population of hatchery and wild smolts, respectively, migrating through Lower Granite (LGR; passage index data accessed from www. FPC.org, June 2013). Red dots represent in-river groups of acoustic tagged (AT) smolts and blue dots represent AT smolts transported from LGR. AT fish were captured $3 \mathrm{~d}$ before release in 2010 and $4 \mathrm{~d}$ before release in 2011

We attempted to size-match the various treatment types in both years (Table 1). In 2010, the STR FL distribution was not significantly different from the SIR group (all were tagged at Lower Granite Dam); however, the CIR group (tagged at John Day Dam) had significantly more large individuals than the SIR group (Wilcoxon rank sum test, p < 0.05). In 2011, the size ranges were similar for the 4 treatment types, but the FL distribution of the SIR group was significantly different (i.e. there were more larger individuals in the SIR group) than the STR MCIR and UCIR groups (Wilcoxon rank sum test, $\mathrm{p}<0.05$ ).

In 2010, at John Day Dam, we collected and tagged CIR smolts during the first half of the smolt seaward migration, and at Lower Granite Dam, we collected and tagged smolts (SIR and STR) during the latter part of the smolt seaward migration (Fig. 4). In 2011, we were able to tag smolts concurrently at both Bonneville (SIR, UCIR, MCIR groups) and Lower Granite (STR group) Dams, and we released smolts across the majority of the seaward run time.

Because we did not tag smolts concurrently at the 2 dams in 2010, SIR smolts were released later than the CIR smolts; however, SIR and STR smolts, which were collected at Lower Granite Dam, were released/transported on approximately the same days (Fig. 2). In 2011, SIR, MCIR and UCIR groups were released concurrently, and STR groups were released on the same days as the early May and midMay in-river groups.

\section{Tag specifications and surgical protocol}

All work involving live fish met the standards laid out by the Canadian Council on Animal Care and was annually reviewed and approved by the Animal Care Committee of Vancouver Island University, Nanaimo, BC, Canada (application no. 2009-11R). We surgically implanted yearling Chinook salmon smolts with V7-2L $(69 \mathrm{kHz}, 7 \mathrm{~mm} \times 20 \mathrm{~mm}, 1.6 \mathrm{~g}$ in air, $0.75 \mathrm{~g}$ in water) acoustic transmitters (VEMCO, Amirix System). All acoustic tags transmitted a unique ID code and were programmed to provide operational lifespans long enough to cover the observed duration of the migration to the Lippy Point sub-array. In 2010, the rated lifespan of the tags was either 52 or $95 \mathrm{~d}_{\text {; }}$ these were evenly allocated between treatment groups as an assessment of the effects of tag programming on detection probability (not reported here). In 2011, the rated lifespan of all tags was $51 \mathrm{~d}$.

A $12 \mathrm{~mm}(0.1 \mathrm{~g})$ PIT tag was also placed in the body cavity (through the incision) of all acoustic tagged smolts to ensure that tagged smolts were diverted back into the river at the juvenile fish bypass facilities and not transported for release below Bonneville Dam, as well as to detect any tagged smolts returning as adults. Acoustic tag burdens (Table 1) were generally lower than the maximum recommended for Chinook salmon smolts (Brown et al. 2006, 2010) and were similar to the tag burden ranges in our previ- 
ously conducted tag effects studies which demonstrated little to no effect of V7 transmitters on survival and retention in Columbia River Basin yearling Chinook smolts $\geq 130 \mathrm{~mm}$ FL (Rechisky \& Welch 2010). Further, as part of the present study, we conducted a tag effect study at Bonneville Dam in 2011; after 35 d, survival of the acoustic tagged group held back at the dam was $97 \%$ and tag retention was $99 \%$ (Porter et al. 2012).

The same surgical protocol was used in both years for all treatment types; a detailed description is provided in Rechisky \& Welch (2010). In brief, portable surgical units were assembled on site, and fish surgery was carried out by experienced, veterinarian-trained staff. Fish were anaesthetized individually in $70 \mathrm{ppm}$ MS-222 buffered with $140 \mathrm{ppm}$ $\mathrm{NaHCO}_{3}$. FL was measured to the nearest mm, and weight was measured to the nearest $0.1 \mathrm{~g}$. A maintenance dose of buffered anesthetic (50 ppm) was pumped through the fish's mouth and over the gills while an incision was made at the ventral midline, midway between the pelvic and pectoral fins. Each smolt was double tagged by placing a PIT and acoustic tag through the incision into the peritoneal cavity, and 1 or 2 absorbable sutures were used to close the incision. Immediately following surgery, fish were placed into a recovery bath and monitored. Fish generally regained equilibrium and reactivity within minutes. After release, we uploaded the PIT tag metadata into the Columbia River Basin PIT Tag Information System (PTAGIS) database maintained by the Pacific States Marine Fisheries Commission (PSMFC, Portland, OR, USA). Both the acoustic tagging metadata and the tracking data from the array were provided to the Pacific Ocean Shelf Tracking (POST) project, which is now managed by the Ocean Tracking Network (OTN, Halifax, NS, Canada).

\section{Acoustic array elements and location}

In 2010, we tracked acoustic tagged smolts from the SIR release site in the Snake River (Lower Granite Dam) through the hydrosystem, lower Columbia River and estuary, plume and coastal ocean to southeast Alaska, a total of $2300 \mathrm{~km}$ (Fig. 1). In 2011, we tracked smolts from the common release site below Bonneville Dam through the lower Columbia River and estuary, plume and coastal ocean to north-western Vancouver Island, a total of $750 \mathrm{~km}$.

The acoustic telemetry array was composed of individual VEMCO receivers positioned above the seabed of the continental shelf or above the riverbed to form a series of listening lines or acoustic sub-arrays (referred to as 'sub-arrays'). Individual receivers recorded the date and time that acoustic transmitters (tags) were detected, and these detections were used to estimate the survival of each treatment group to each sub-array.

Sub-arrays upstream of Bonneville Dam were deployed in several reservoirs created by the Federal Columbia River Power System: in Lake Bryan below Lower Granite Dam in the Snake River, in Lake Wallula below the confluence of the Columbia and Snake Rivers, and in Lake Celilo downstream of John Day Dam in the lower Columbia River. These sub-arrays were removed in 2011 because all fish were released downstream near Bonneville Dam.

In 2010, sub-arrays downstream of Bonneville Dam were deployed in the lower Columbia River in McGowans Channel below Bonneville Dam (the last dam), in the estuary near Crims Island, near Astoria, $\mathrm{WA}$, and near the river mouth at Sand Island. This area is collectively referred to as the lower river and estuary. In 2011, the McGowans Channel and Crims Island sub-arrays were removed.

During the 2010 study, marine components of the array were deployed in coastal ocean waters off southern Washington (near Willapa Bay), northwestern Vancouver Island (Lippy Point, BC) and southeast Alaska (Graves Harbor). These sub-arrays extended from near-shore out to $\sim 200 \mathrm{~m}$ depths. In 2011, the Graves Harbor sub-array was removed, a sub-array was deployed in coastal Oregon waters near Cascade Head to detect any southward migrating smolts, and all coastal sub-arrays were extended farther offshore out to $\sim 500 \mathrm{~m}$ depths. For this study, the hydrosystem is defined as the area between Lake Bryan and McGowans Channel, the lower river and estuary is defined as the tidal area ranging from McGowans Channel to Sand Island, the plume is defined as the area from Sand Island to Willapa Bay, and the coastal ocean is defined as the area between Willapa Bay and Lippy Point. A more detailed description of array elements, location and performance can be found in Porter et al. (2012).

\section{Base model selection and survival estimation}

Estimates of smolt survival $(\varphi)$ and detection probability on each sub-array $(p)$ were calculated for each treatment group (SIR, CIR and STR in 2010 and SIR, MCIR, UCIR and STR in 2011) using a modified Cormack-Jolly-Seber (CJS) model (Cormack 1964, Jolly 1965, Seber 1965) for live-recaptured animals in Pro- 
gram MARK (White \& Burnham 1999). The CJS model uses maximum likelihood estimation to derive estimates of $\varphi$ and $p$ parameters and the sampling variance of those parameters. We further modified these models to test whether there was support for hydro- and transport-DM, or differential survival of the treatment groups.

For each year, the analysis followed a series of steps. First, we screened the detection data and formed detection histories for each tagged individual. Second, we assessed goodness of fit (GOF) of the data to the model. Third, we investigated the effect of treatmenttype on $p$ in order to determine the structure of the model that provided the best estimates of $\varphi$ for each treatment type (our base model). Finally, we compared the base model to models used for hypothesis testing. We provide details of each of these steps below.

All acoustic detection data from the array were screened for potential false positive detections, which were rare; excluded data typically formed $<0.2 \%$ of the total recorded detections (see Porter et al. 2012 for screening criteria). All tagged smolts were included in the analyses, regardless of their specific route through the dams (e.g. spill, bypass or turbine). Court-ordered spill levels were met or exceeded at the 4 lower Snake River dams and the 4 lower Columbia River dams during our study, which reduced the chance that smolts migrated through the turbines and bypasses. Detection histories for each tagged individual were then formed from the screened data.

We assessed the GOF of our data to the CJS model prior to parameter estimation. To do so, we fit the most general CJS model $(\varphi$ [type $\times$ segment] $p$ [type $\times$ site], $\varphi$ and $p$ estimated for each treatment type in each reach and on each sub-array) and assessed GOF with the median $\hat{c}$ test within Program MARK to yield an overdispersion factor, $\hat{c}$ (Cox \& Snell 1989). In both years, there was no overdispersion due to lack of fit of the data to the model, i.e. $\hat{c}=1$ in 2010 and 0.94 in 2011 ; therefore, no correction to the estimated standard errors was necessary.

Although all fish were implanted with the same model of acoustic tag, we wanted to ensure that assuming a common detection efficiency for each sub-array would not bias the relative survival estimates. Therefore, we compared the performance of models where $p$ parameters were estimated in 3 different ways. We hypothesized that $p$ may be similar for the treatment types at each sub-array ( $p$ [site]), that $p$ may vary for each treatment type at each subarray ( $p$ [type $\times$ site]), or that $p$ may vary for the different treatment types at each sub-array in freshwater (FW), but be similar across treatment types in the ocean (specifically the Willapa Bay sub-array [WIL], $\mathrm{p}$ [type $\times$ site $\times \mathrm{FW}+$ site $\times$ WIL]). The number of $\varphi$ parameters in each model did not vary since one of our goals was to produce estimates of survival for each treatment type between each sub-array $(\varphi$ [typexseg]) in each year.

For all models, we fixed the $p$ of the Lippy Point subarray to 0.67 . We used a fixed value because we wished to estimate survival to Lippy Point, but within the CJS model, survival and detection are confounded at the final detection site. (Although there was a subarray in southeast Alaska in 2010, too few fish were detected on this sub-array [ $\mathrm{n}=3 \mathrm{STR}, \mathrm{n}=0 \mathrm{SIR}, \mathrm{n}=0$ $\mathrm{CIR}]$ to provide adequate information regarding the performance of the Lippy Point sub-array; the Alaskan sub-array was not deployed in 2011). By fixing $p$, we could estimate $\varphi$ conditional on this assumed value. Using this fixed value was a reasonable approach for several reasons: (1) CJS analyses of $p$ for other fully intact marine sub-arrays with similar receiver geometry, bounded by landmasses on either side, and with ample detections beyond the sub-array in question (which renders them directly estimable) showed that marine detection rates are very consistent across multiple sites and multiple years ( $\sim .67$ for V7 transmitters at 3 sites in 4 years, Welch et al. 2011); (2) marine receivers were deployed at approximately equal spacing to the Welch et al. (2011) study; (3) the smolt distribution on the Lippy Point sub-array was centered on the inner to middle continental shelf (Rechisky et al. 2012, 2013), indicating that fish were confined to the shelf; and (4) if estimates at Lippy Point are biased they should be equally biased for both treatment types, as identical acoustic tags were used in each year. Ideally, we would have fixed $p$ at Lippy Point to equal the estimated $p$ at Willapa Bay; however, receiver loss at Willapa Bay due to commercial fishing reduced detection efficiency, whereas the Lippy Point sub-array did not suffer losses due to fishing. Because the key scientific tests are (1) whether SIR smolts have lower post-Bonneville Dam survival than the CIR smolts and (2) whether STR smolts have lower post-Bonneville Dam survival than the SIR smolts, some uncertainty in the value of this final sub-array's detection probability is acceptable; however, we do require the assumption that the 2 tagged groups behaved similarly (i.e. that travel rate and potential offshore emigration, beyond the shelf arrays, were equal).

We used Akaike's Information Criteria corrected for low sample size $\left(\mathrm{AIC}_{\mathrm{c}}\right)$ to evaluate the strength of evidence for the 3 competing base models formulated in each year. The model with the lowest $\mathrm{AIC}_{\mathrm{c}}$ and highest probability of fitting the data as indi- 
cated by the $\mathrm{AIC}_{\mathrm{C}}$ weight $\left(\mathrm{WAIC}_{\mathrm{C}}\right.$ ) was chosen as the best base model (Burnham \& Anderson 2002, Wagenmakers \& Farrell 2004). The segment survival estimates and standard errors reported (see Tables 2 \& 3) were obtained from this model. Parameter confidence intervals were estimated using the profile likelihood method within Program MARK. We did not investigate other potential causes of variability in $\varphi$ (e.g. we did not include fish body size, travel time or release-timing covariates in our models). Prior assessments of other sources of variability such as tag loss, tagging induced mortality, tag operational lifespan and survival differences between taggers (surgical skill), as well as fish body size, indicated that these factors did not have significant influence on the survival estimates during the time required for the freely migrating tagged smolts to pass Lippy Point, BC (Porter et al. 2012).

For each treatment type, we then estimated cumulative survival in the co-migration corridor between Bonneville Dam and northwestern Vancouver Island as the product of the segment-specific survival estimates. Survival of the SIR group in the hydrosystem (to Lake Celilo below John Day Dam) in 2010 was calculated similarly as the product of segment-specific survival estimated from Lower Granite Dam to Lake Celilo. All variances on cumulative estimates were estimated with the delta method.

\section{Strength of evidence for delayed mortality}

To assess evidence of transport-DM, hydro-DM and/or differential survival of tagged groups of yearling Chinook salmon, we compared models which represented differences in survival of 2 treatment groups with reduced models which were formulated to represent the alternative hypothesis that there was no difference in survival of those groups. In all comparisons, the base models described above served as the delayed mortality or differential survival models since they were parameterized to produce estimates of $\varphi$ for all 3 treatment types (STR, SIR and CIR) in each migration segment, and henceforth are referred to as base/DM models. In the reduced models, data from treatment types which were being compared were pooled and only 1 common $\varphi$ parameter was estimated for each migration segment. To evaluate the strength of evidence for the competing models, we assessed the difference in the $\mathrm{AIC}_{\mathrm{C}}$ scores $\left(\Delta \mathrm{AIC}_{\mathrm{C}}\right)$ and the ${ }_{W A I C}$ to determine which model had the highest probability of fitting the data (Burnham \& Anderson 2002, Wagenmakers \& Farrell 2004). For instance, if a reduced model had a lower $\mathrm{AIC}_{\mathrm{C}}$ score and higher $W_{\mathrm{AIC}}$, i.e. if the data fit the reduced model best, then there was little or no support for delayed mortality in Snake River smolts. If the base/DM model had more support than the reduced model, it was necessary to then examine the $\varphi$ parameter estimates (from the base/DM model) to determine which treatment group had better survival. Delayed mortality hypotheses would have empirical support if the group hypothesized to have greater stress indeed had poorer survival.

The 2010 base/DM model served as the transportDM model in the transport-DM hypothesis test and also served as the differential survival model in the test of differential survival for in-river groups. To assess evidence of transport-DM in 2010, we compared the base/DM model to a reduced model (transport H1) which represented the alternative hypothesis that no transport-DM occurred for the STR treatment type relative to the SIR treatment type in the lower river and estuary, and the coastal ocean, i.e. survival was similar for the 2 groups. Thus, in the transport H1 model, data used to estimate SIR and STR base/DM model parameters SIR5-9 and STR1-5 were combined to estimate transport H1 model parameters S1-5 (Fig. 5a).

To test whether differential survival occurred for SIR and CIR groups in 2010, we compared the 2010 base/DM model to a model that represented the alternative hypothesis that survival of SIR and CIR treatment types was similar (model: hydro H1). In the hydro H1 model the effect of treatment (population) was removed in common migration segments where SIR and CIR smolts were tracked. The common tracking area began at Lake Celilo in 2010; thus beginning at this site, data for the groups were pooled and only 1 common survival parameter was estimated between each sub-array from Lake Celilo to Lippy Point (Fig. 5a: data used to estimate base/DM model parameters SIR4-9 and CIR2-7 were combined into hydro H1 model parameters IR1-6). We also formulated a model that more specifically represented differential survival downstream of Bonneville Dam (model: DM2). Similar to the base/DM model, the DM2 model estimated survival parameters between each detection site from Lake Bryan to Lake Celilo for the Snake River population, and separate survival parameters for each population in the lower river and estuary and coastal ocean; however, a common survival parameter was estimated for both populations between Lake Celilo and McGowans Channel (Fig. 5a: data used to estimate base/DM model parameter SIR4 and CIR2 were combined to estimate DM2 model para- 
meter R1). We do not explicitly refer to this test as hydro-DM since the source populations contributing to the tagged CIR smolts were unknown in 2010.

The 2011 base/DM model served as the transport-DM model in the transport-DM hypothesis test and also served as the hydro-DM model in the hydroDM hypothesis test. For the transportDM test, the reduced model (transport H1) represented the alternative hypothesis that no transport-DM occurred for the SIR treatment type relative to the STR treatment type in the lower river and estuary, and the coastal ocean. Thus, data used to estimate base/DM model parameters SIR1-4 and STR1-4 were combined to estimate transport $\mathrm{H} 1$ model parameters S1-4 (Fig. 5b).

We then compared the 2011 base/DM model to a reduced model (hydro $\mathrm{H} 1_{\text {MCIR }}$ ) which represented the alternative hypothesis that no hydro-DM occurred for the SIR treatment type relative to the MCIR treatment type. Thus, data used to estimate base/DM model parameters SIR1-4 and MCIR1-4 were combined to estimate hydro $\mathrm{H} 1_{\mathrm{MCIR}}$ model parameters IR1-4. We repeated this process to assess whether the data supported differential survival of SIR and UCIR treatment types as well (see Fig. 5b: data used to estimate base/DM model parameters SIR1-4 and UCIR1-4 were combined to estimate hydro $\mathrm{H} 1_{\text {UCIR }}$ model parameters IR1-4). We do not explicitly call this a test of hydro-DM since the UCIR and SIR smolts migrate through a similar number of dams prior to reaching the ocean; however, the results are of significant interest

Fig. 5. Oncorhynchus tshawytscha. Schematic of study design and models used to estimate survival $(\varphi)$ and detection probability $(p)$, and to assess the strength of evidence for delayed-mortality in yearling smolts from the Snake and Columbia Rivers in (a) 2010 and (b) 2011. Thick arrows indicate seaward migration of all release groups (R). Parameters not in bold are identical to base/DM model parameters and are included to show the full model parameterization of alternative models. Abbreviations defined in Fig. 1
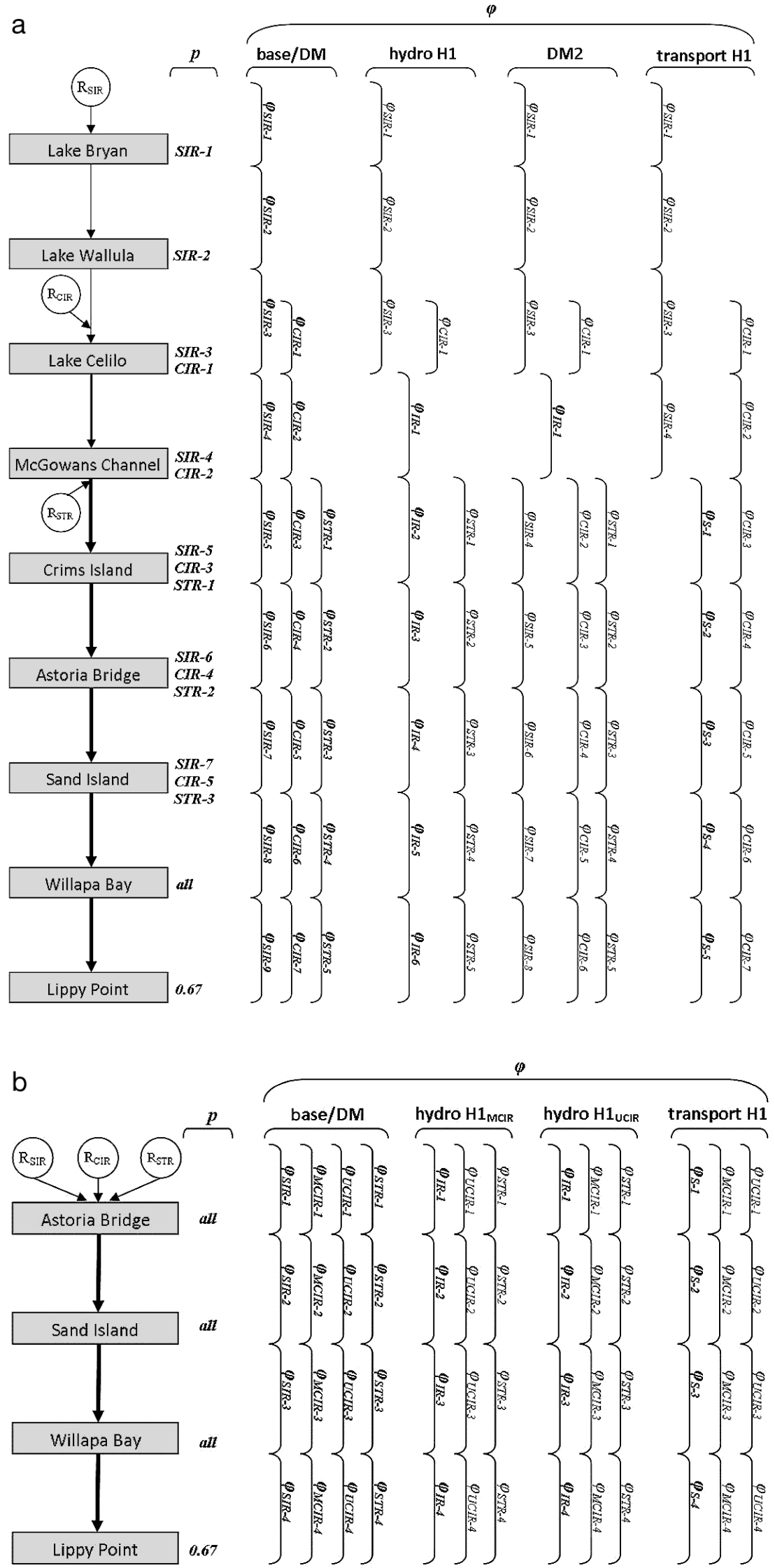
because they provide the first data on the early marine survival of upper Columbia River yearling Chinook.

\section{Model assumptions}

Standard CJS model assumptions applied for all sub-arrays: (1) every tagged individual of each group has equal survival probability and equal probability of detection following release, (2) sampling periods are instantaneous, (3) emigration is permanent and (4) tags are not lost. For coastal ocean sub-arrays that were unbounded on the offshore end, we required 3 additional assumptions: (5) fish departing the Columbia River swim north, (6) their migration is confined to the coastal zone spanned by the sub-arrays and (7) detection probability of the Lippy Point sub-array is equivalent to that of other coastal sub-arrays with similar geometry (Welch et al. 2011; see 'Materials and methods: Base model selection and survival estimation'). Assumptions (5) and (6) are supported by evidence from our prior studies (Rechisky et al. 2012, 2013), as well as ocean sampling programs that demonstrate that juvenile spring Chinook salmon remain almost entirely on the continental shelf as they migrate north (Miller et al. 1983, Fisher \& Pearcy 1995, Bi et al. 2007, Trudel et al. 2009, Peterson et al. 2010). As well, the Cascade Head sub-array (Fig. 1), which was deployed in 2011 to further assess assumption (5), detected only 6 tagged smolts, 1 of which was later detected first on the Willapa Bay and then the Lippy Point sub-arrays (see Discussion). Assumption (7) can only be validated by the addition of another sub-array; however, we previously demonstrated that changes in the $p$ of Lippy Point will not affect the relative survival of the various treatment types (Rechisky et al. 2012, 2013).

\section{RESULTS}

\section{Stock identification}

Of the 580 smolts released at Bonneville Dam in 2011, 55 fish were identified by GSI as fall-run yearling Chinook smolts (interior Columbia River summer/fall-run reporting group) and were excluded from the study. Although we hoped to tag primarily Snake and mid-Columbia River smolts at Bonneville Dam, many fish (386 of the remaining 525) were identified post-release by GSI as upper Columbia River spring Chinook. Only 59 smolts were identified as mid-Columbia spring Chinook, and 80 smolts were identified as Snake River spring/summer Chinook. Of the 200 smolts released at Lower Granite Dam, 170 were identified as spring or summer-run Snake River Chinook, using PBT, and the remaining 30 Chinook were assumed to be spring-run fish originating from the Snake River based on the fact that they were captured in the Snake River Basin and that no fall Chinook were identified using GSI. Most of these smolts (24 of 30) were identified by GSI as Snake River spring/summer Chinook, but we chose to use collection site as the stock determinant in the absence of PBT results to avoid introducing low level mis-assignment contributed by GSI.

Most hatchery smolts originating from the Snake River Basin were matched with their parents using PBT, and were thus identified to their specific hatchery $(86 \%$ of the 197 Snake River hatchery fish at Lower Granite Dam, and $73 \%$ of the 78 Snake River hatchery fish at Bonneville Dam). Of these fish, approximately $40 \%$ of SIR and STR smolts originated from the Rapid River Hatchery (Fig. 6). South Fork

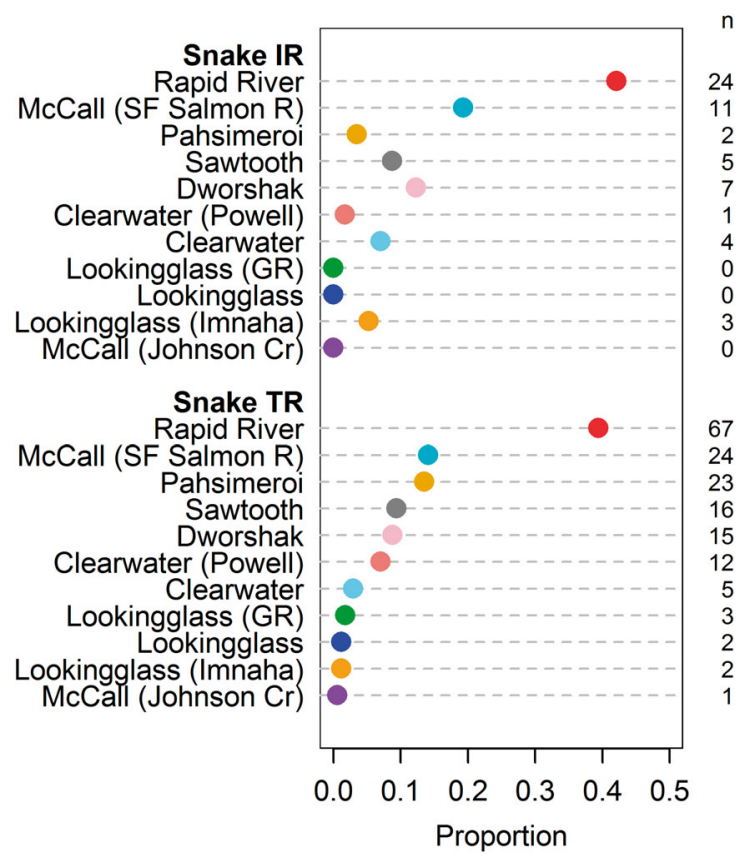

Fig. 6. Oncorhynchus tshawytscha. Hatchery allocation of acoustic-tagged Snake River spring/summer Chinook in 2011 determined by parentage-based tagging (PBT). Transported (TR) smolts were collected at Lower Granite Dam (170 of 200 smolts were identified with PBT). In-river (IR) smolts were collected at Bonneville Dam (57 of 80 smolts were identified with PBT). Hatcheries listed more than once indicate that the tributary or satellite facility in which the fish are reared (details given in parentheses) is different from the hatchery's location. SF: South Fork; GR: Grand Ronde. Other abbreviations as in Fig. 1 
Salmon River smolts from McCall Hatchery made up an additional $21 \%$ of the SIR group and $14 \%$ of the STR group, and the remaining smolts originated from 9 other Snake River spring/summer Chinook populations. Sample sizes were too small to estimate survival for individual hatchery groups or for naturally spawning smolts (only 14 tagged smolts had an intact adipose fin and 9 of these were identified as hatchery fish using PBT).

\section{Base model selection results and survival estimates}

In 2010, there was more support for a base model where detection probability $p$ varied for the treatment types at each sub-array in freshwater, but was similar across treatment types at Willapa Bay ( $p$ [type $\times$ site $\times \mathrm{FW}+$ site $\times \mathrm{WIL}] ; \Delta \mathrm{AIC}_{\mathrm{c}} \geq 2.5$ for competing models and ${ } \mathrm{AIC}_{\mathrm{C}}=77 \%$ ). In 2011, there was more support for a base model where $p$ was similar for all treatment types at each sub-array up to and including Willapa Bay ( $p$ [site], $\Delta \mathrm{AIC}_{\mathrm{C}} \geq 9.9$ for competing models and ${ }_{W A I C}=99 \%$ ). Estimates of $p$ are reported in Table S1 in the supplement.

Estimated survival in the lower river and estuary (from base/DM models) was high for all treatment groups in both years and ranged between 0.81 and 1.0 (Tables $2 \& 3$; see Table S2 in the supplement for the number of fish detected on each sub-array). Survival in the plume ranged between 0.46-0.79 in 2010 and only $0.14-0.30$ in 2011. Coastal ocean survival beyond the plume ranged between $0.28-0.43$ in 2010 and 0.14-0.39 in 2011.

Cumulative post-Bonneville Dam survival to northwestern Vancouver Island (Lippy Point) was similar for all 3 treatment types in 2010 (0.14-0.19; Fig. 7). In 2011, SIR, MCIR and UCIR treatment types had remarkably similar survival to Lippy Point (0.07-0.08), but the STR group was considerably lower, only 0.015 .

\section{Strength of evidence for transportation- induced delayed mortality}

Model selection results indicated that in 2010 the base/DM model had slightly more support (lower $\mathrm{AIC}_{\mathrm{c}}$ and higher ${ }_{\mathrm{AAIC}}$ ) than the transport H1 model (Table 4). Thus, there were some differences in survival of STR and SIR smolts; however, the estimates indicate that survival in the plume was lower for STR smolts relative to SIR smolts, but survival in the coastal ocean beyond the plume was higher for STR smolts (Fig. 8). Lower river and estuary survival varied as well. As cumulative post-Bonneville survival to Lippy Point was slightly greater for STR smolts (Fig. 7), there was no support for transport-DM in 2010.

Model selection results for the 2011 data showed that the transport H1 model had slightly more support than the base/DM model (Table 4). Transported smolts experienced similar survival as the SIR smolts in the lower river and estuary but relatively lower survival in both the plume and coastal ocean (Fig. 8). Although the transport H1 model had the highest probability of fitting the data and did not support the transport-DM hypothesis, survival estimate confi-

Table 2. Oncorhynchus tshawytscha. Estimated survival, $\varphi( \pm \mathrm{SE})$, of acoustic tagged, yearling Chinook salmon, 2010. Snake in-river (SIR) smolts were collected and released at Lower Granite Dam (LGR). Columbia in-river (CIR) smolts were collected at John Day Dam (JDA) and released $42 \mathrm{~km}$ upstream of JDA. Snake River transported (STR) smolts were collected at Lower Granite Dam and released 7 to $12 \mathrm{~km}$ below Bonneville Dam (BON, located upstream of McGowans Channel, MCG; see Fig. 1). REL: release site; LRE: lower Columbia River and estuary; NA: not applicable. Definitions of abbreviations for detection sites delineating migration segments are found in Fig. 1

\begin{tabular}{|c|c|c|c|c|}
\hline \multirow{2}{*}{ Habitat } & \multirow{2}{*}{$\begin{array}{l}\text { Migration segment } \\
\text { (distance, km) }\end{array}$} & \multicolumn{3}{|c|}{ Treatment type } \\
\hline & & SIR & CIR & STR \\
\hline \multirow[t]{2}{*}{ Hydrosystem } & REL-LAC (355/42) & $0.46 \pm 0.04^{\mathrm{a}}$ & $0.95 \pm 0.03$ & NA \\
\hline & LAC-MCG (116) & $0.77 \pm 0.07$ & $0.77 \pm 0.03$ & NA \\
\hline \multirow[t]{3}{*}{ LRE } & MCG-CRI (137) & $0.96 \pm 0.06$ & $1 \pm 0$ & $0.85 \pm 0.04$ \\
\hline & CRI-AST (64) & $0.97 \pm 0.05$ & $0.90 \pm 0.03$ & $0.88 \pm 0.05$ \\
\hline & AST-SDI (15) & $0.88 \pm 0.07$ & $0.89 \pm 0.07$ & $1 \pm 0$ \\
\hline Plume & SDI-WIL (48) & $0.79 \pm 0.13$ & $0.46 \pm 0.06$ & $0.58 \pm 0.07$ \\
\hline Ocean & WIL-LIP (485) & $0.28 \pm 0.07$ & $0.37 \pm 0.06$ & $0.43 \pm 0.07$ \\
\hline
\end{tabular}

Table 3. Oncorhynchus tshawytscha. Estimated survival, $\varphi( \pm \mathrm{SE})$, of acoustic tagged, yearling spring Chinook salmon, 2011. Snake in-river (SIR) smolts and mid- and upper Columbia in-river (MCIR, UCIR) smolts were collected and released at Bonneville Dam, and thus it was not possible to estimate hydrosystem survival. Snake River transported (STR) smolts were collected at Lower Granite Dam and released 7 to $12 \mathrm{~km}$ below Bonneville Dam. REL: release site; LRE: lower Columbia River and estuary. Definitions of abbreviations for detection sites delineating migration segments are found in Fig. 1

\begin{tabular}{|c|c|c|c|c|c|}
\hline \multirow{2}{*}{$\begin{array}{l}\text { Hab- } \\
\text { itat }\end{array}$} & \multirow{2}{*}{$\begin{array}{l}\text { Migration segm. } \\
\text { (distance, km) }\end{array}$} & \multicolumn{4}{|c|}{ — Treatment type - } \\
\hline & & SIR & MCIR & UCIR & STR \\
\hline LRE & REL-AST (201) & $0.83 \pm 0.05$ & $0.91 \pm 0.04$ & $0.81 \pm 0.02$ & $0.83 \pm 0.03$ \\
\hline LRE & AST-SDI (15) & $1 \pm 0$ & $1 \pm 0.08$ & $0.98 \pm 0.04$ & $0.92 \pm 0.06$ \\
\hline Plume & SDI-WIL (48) & $0.23 \pm 0.07$ & $0.22 \pm 0.07$ & $0.30 \pm 0.04$ & $0.14 \pm 0.04$ \\
\hline Ocean & WIL-LIP (485) & $0.39 \pm 0.18$ & $0.39 \pm 0.21$ & $0.34 \pm 0.07$ & $0.14 \pm 0.09$ \\
\hline
\end{tabular}




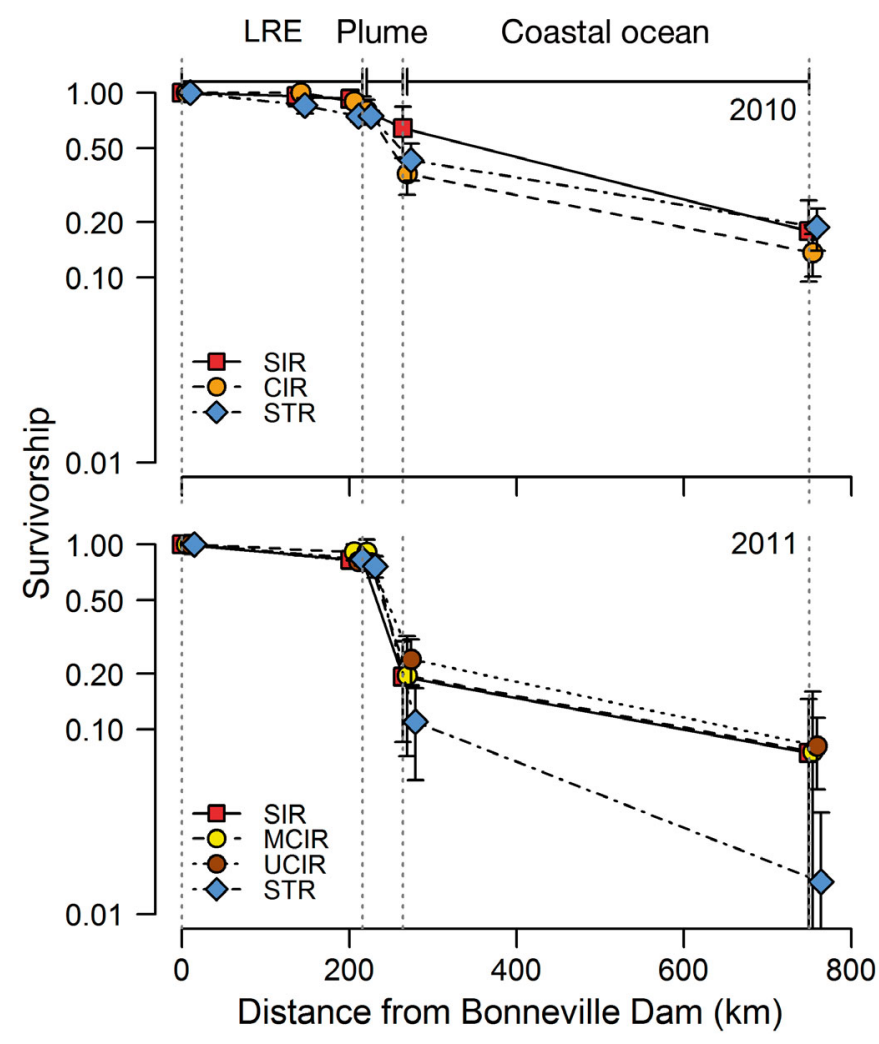

Fig. 7. Oncorhynchus tshawytscha. Post-Bonneville Dam survival of yearling smolts to north-western Vancouver Island. Kilometer 0 represents the location of the McGowans Channel sub-array and the release site for Snake transported (STR) smolts (which are both $\sim 10 \mathrm{~km}$ below Bonneville Dam), and the Bonneville Dam juvenile monitoring facility where IR smolts were released in 2011. LRE: lower river and estuary; SIR: Snake in-river; CIR: Columbia in-river; MCIR: mid-Columbia in-river; UCIR: upper Columbia in-river. Data points were adjusted to prevent overlap of $95 \%$ confidence intervals (bars). Note that survivorship is plotted on a log scale to show differences in survival at low levels dence intervals, particularly at Lippy Point, were very wide in this year. Taken together, the cumulative post-Bonneville survival to Lippy Point was considerably lower for STR smolts, providing some evidence that transport-DM may have occurred (Fig. 7; but see 'Discussion').

\section{Strength of evidence for hydrosystem-induced delayed mortality}

Model selection results indicated that the DM2 model had more support in 2010 and that there was very little support for the hydro H1 model (Table 5). Thus, differential survival occurred for SIR and CIR smolts; however, the survival estimates indicated that this result was driven by the abrupt decline of the CIR treatment group (not the SIR group) in the plume shortly after ocean entry (Fig. 9, Table 2).

In 2011, model selection results indicated that the hydro $\mathrm{H} 1_{\mathrm{MCIR}}$ model assessing hydro-DM of SIR relative to MCIR had more support (Table 5). Thus, there was no support for hydro-DM in 2011. The hydro $\mathrm{H} 1_{\text {UCIR }}$ model assessing comparative survival of the SIR treatment type relative to UCIR treatment type also had more support. Thus, survival of all 3 in-river treatment types was similar in all of the migration segments (Fig. 9).

\section{DISCUSSION}

Hydrosystem-induced delayed mortality would have important implications for salmon management, as human-induced changes to freshwater

Table 4. Oncorhynchus tshawytscha. Model selection results investigating transportation-induced delayed mortality (transport-DM) for transported Snake River yearling Chinook salmon relative to in-river migrating Snake River Chinook salmon. Base/DM models: survival was estimated for each treatment type in each migration segment; transport H1 model: common survival parameters were estimated for both treatments in the lower Columbia River estuary and ocean (LREO); $\varphi$ : survival probability; $p$ : detection probability; type: treatment type; seg: migration segment; river: river upstream of Bonneville Dam; $\mathrm{AIC}_{\mathrm{c}}$ : Akaike's Information Criteria with low sample size; $\Delta \mathrm{AIC}_{\mathrm{c}}: \mathrm{AIC}_{\mathrm{c}}-\mathrm{AIC}_{\mathrm{c} \text { mini }} \mathrm{wAIC}_{\mathrm{c}}$ : Akaike weight; $L$ : model likelihoodi $\mathrm{K}$ : number of parameters

\begin{tabular}{|c|c|c|c|c|c|c|c|c|}
\hline $\begin{array}{l}\text { Model } \\
\text { Description }\end{array}$ & Model $^{\mathrm{a}}$ & $\mathrm{AIC}_{\mathrm{c}}$ & $\Delta \mathrm{AIC}_{\mathrm{c}}$ & $w \mathrm{AIC}_{\mathrm{c}}$ & $L$ & $\mathrm{~K}$ & $\begin{array}{l}\text { Devi- } \\
\text { ance }\end{array}$ & Outcome \\
\hline \multicolumn{9}{|l|}{2010} \\
\hline Base/DM & $\varphi$ (type×seg) $p$ & 9685.0 & 0 & 0.74 & 1 & 37 & 257.1 & \multirow{2}{*}{$\begin{array}{l}\text { No transport-DM; } \varphi \text { is } \\
\text { variable (see Table 2) }\end{array}$} \\
\hline Transport H1 & $\varphi($ type $\times$ seg $\times$ river $+\operatorname{seg} \times$ LREO $) p$ & 9687.1 & 2.1 & 0.26 & 0.35 & 32 & 269.4 & \\
\hline \multicolumn{9}{|l|}{2011} \\
\hline Transport H1 & $\varphi(\operatorname{seg}) p$ & 2523.4 & 0 & 0.72 & 1 & 15 & 31.6 & \multirow{2}{*}{$\begin{array}{l}\text { Weak support for } \\
\text { transport-DM }\end{array}$} \\
\hline Base/DM & $\varphi$ (typexseg) $p$ & 2525.3 & 1.92 & 0.28 & 0.38 & 19 & 25.4 & \\
\hline
\end{tabular}




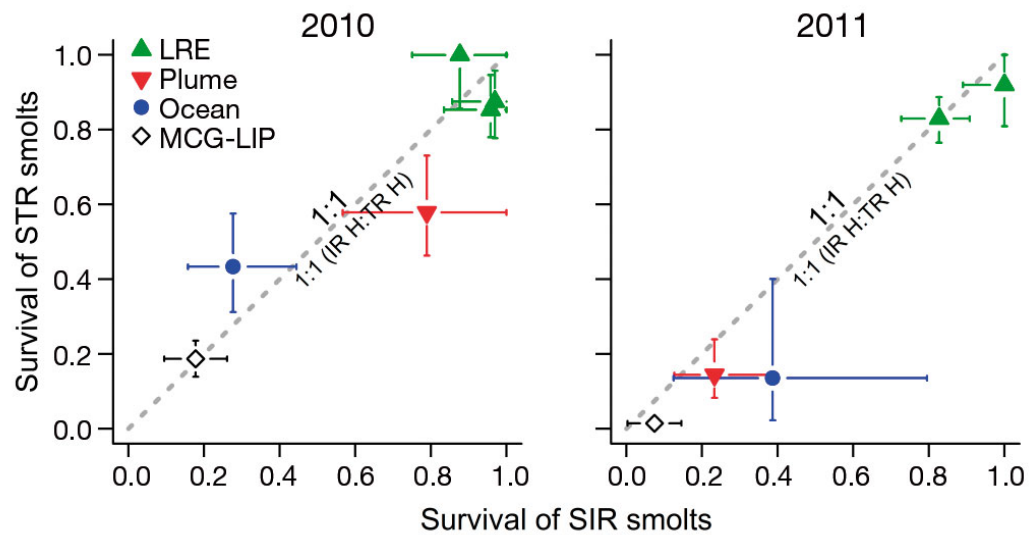

Fig. 8. Oncorhynchus tshawytscha. Comparative survival of in-river migrating Snake River yearling Chinook (SIR) with transported yearling Chinook (STR) in common migration segments. Lower river and estuary (LRE) survival was divided into 3 migration segments in 2010, and 2 segments in 2011. MCG-LIP is the cumulative survival estimate from McGowans Channel to Lippy Point. The dashed 1:1 line represents equal survival. Points falling below the line represent lower survival of STR smolts. The dashed line also represents the mean ratio of smolt-to-adult return rates (SAR) of in-river migrating Snake River hatchery yearling Chinook (IR H) to the SAR of transported Snake River hatchery yearling Chinook (TR H), reported as ' $D$ ' in Comparative Survival Study reports (Tuomikoski et al. 2012). Only 3 to $5 \%$ of acoustic tagged Snake River fish were wild; thus we did not plot the IR W:TR W ratio for comparison

habitat may affect fitness during the estuarine and marine phases of the life history. Although a significant amount of post-Bonneville Dam mortality occurred by the time Chinook smolts reached northwest Vancouver Island, and there was little to no support for delayed mortality of Snake River Chinook due to migration through the Snake River dams.

If delayed mortality due to hydrosystem-induced stress is expressed in the estuary or within the first month of life in the coastal ocean, we would expect to see reduced post-hydrosystem survival of the Snake in-river migration group relative to the midColumbia in-river migration group. Despite tracking smolts as far as northern Vancouver Island, $750 \mathrm{~km}$ beyond the last dam and for approximately 1 mo after ocean entry, we did not observe lower survival of SIR smolts. Consistent with several studies (Schreck et al. 2006, Clemens et al. 2009, McMichael et al. 2010, Harnish et al. 2012, Rechisky et al. 2012, 2013), survival in the lower river and estuary was high, and although subsequent marine survival was low, smolts originating from the Snake River apparently did not suffer deleterious effects (i.e. extra mortality) from additional dam passage. Thus, our results do not support the hypothesis that hydrosysteminduced stress leads to reduced fitness and reduced survival of Snake River spring Chinook salmon pop-

Table 5. Oncorhynchus tshawytscha. Model selection results investigating differential mortality for in-river migrating Snake River yearling Chinook salmon (SIR) relative to in-river migrating yearling Chinook from the Columbia River (CIR) in 2010, and hydrosystem-induced delayed mortality (hydro-DM) for SIR salmon relative to mid-Columbia River (MCIR) and upper Columbia River (UCIR) yearling Chinook salmon in 2011. DM2 model: survival parameters were estimated for each treatment type in all common migration segments; base/DM models: survival parameters were estimated for each treatment type in the lower Columbia River, estuary and coastal ocean (LREO); hydro H1 model: common survival parameters were estimated for both treatments in the LREO; $\varphi$ : survival probability; $p$ : detection probability; type: treatment type; seg: migration segment; rel-LAC: release to Lake Celilo; LAC-MCG: Lake Celilo to McGowans Channel; river: river upstream of Bonneville Dam. Definitions of abbreviations for model selection are found in Table 4

\begin{tabular}{|c|c|c|c|c|c|c|c|c|}
\hline $\begin{array}{l}\text { Model } \\
\text { Description }\end{array}$ & Model $^{\mathrm{a}}$ & $\mathrm{AIC}_{\mathrm{c}}$ & $\Delta \mathrm{AIC}_{\mathrm{c}}$ & $w \mathrm{AIC}_{\mathrm{c}}$ & $L$ & $\mathrm{~K}$ & $\begin{array}{l}\text { Devi- } \\
\text { ance }\end{array}$ & Outcome \\
\hline \multicolumn{9}{|c|}{ 2010-SIR/CIR } \\
\hline DM2 & $\begin{array}{l}\varphi(\text { type } \times \text { seg } \times \text { rel-LAC }+ \text { seg } \times \text { LAC-MCG } \\
+ \text { type } \times \text { seg } \times \text { LREO) } p\end{array}$ & 9683.0 & 0 & 0.68 & 1 & 36 & 257.1 & \multirow[t]{3}{*}{$\begin{array}{l}\varphi_{\mathrm{SIR}}>\varphi_{\mathrm{CIR}} \text { in } \\
\text { the plume }\end{array}$} \\
\hline Base/DM & $\varphi$ (typexseg) $p$ & 9685.0 & 2.0 & 0.25 & 0.36 & 37 & 257.1 & \\
\hline Hydro H1 & $\varphi($ type $\times$ seg $\times$ river $+\operatorname{seg} \times$ LREO $) p$ & 9687.5 & 4.5 & 0.07 & 0.11 & 32 & 269.7 & \\
\hline \multicolumn{9}{|c|}{ 2011-SIR/MCIR } \\
\hline Hydro H1 & $\varphi(\operatorname{seg}) p$ & 2518.9 & 0 & 0.96 & 1 & 15 & 27.1 & \multirow{2}{*}{ No hydro-DM } \\
\hline Base/DM & $\varphi$ (typexseg) $p$ & 2525.3 & 6.4 & 0.04 & 0.04 & 19 & 25.4 & \\
\hline \multicolumn{9}{|c|}{ 2011-SIR/UCIR } \\
\hline Hydro H1 & $\varphi(\operatorname{seg}) p$ & 2518.2 & 0 & 0.97 & 1 & 15 & 26.4 & \multirow[t]{2}{*}{ No hydro-DM } \\
\hline Base/DM & $\varphi$ (typexseg) $p$ & 2525.3 & 7.1 & 0.03 & 0.03 & 19 & 25.4 & \\
\hline
\end{tabular}




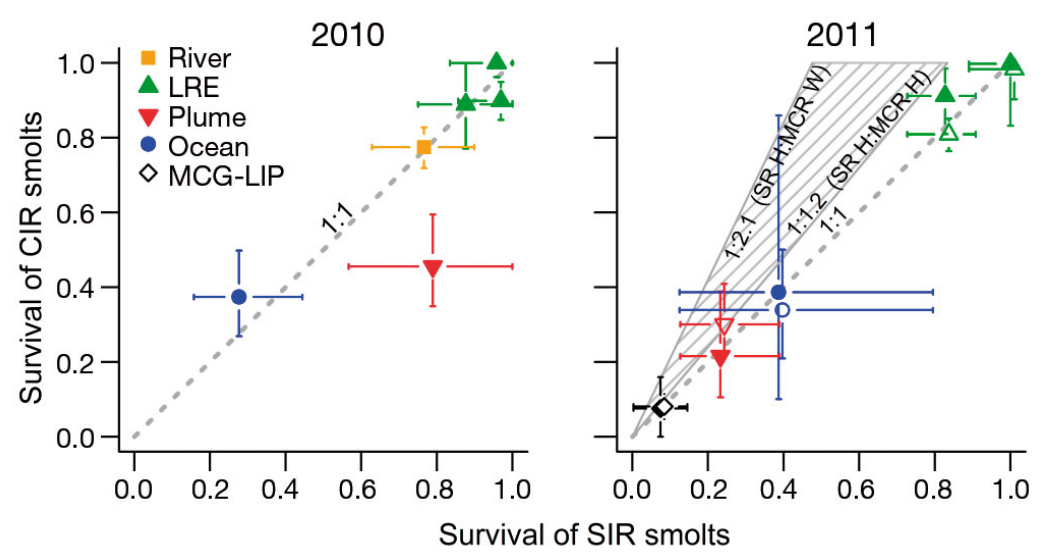

Fig. 9. Oncorhynchus tshawytscha. Comparative survival of in-river migrating Snake River yearling Chinook (SIR) with Columbia River yearling Chinook (CIR) in common migration segments. Lower river and estuary (LRE) survival was divided into 3 migration segments in 2010, and 2 segments in 2011. 'River' is the migration segment between LAC and MCG (see Fig. 1 for abbreviation definitions). MCG-LIP is the cumulative survival estimate from McGowans Channel to Lippy Point. CIR smolts were identified as mid- (closed symbols) and upper (open symbols) Columbia River origin in 2011. The dashed 1:1 line represents equal survival. Points above the line indicate lower survival of SIR smolts. The shaded area is bounded by lines representing the ratio of the mean smolt-to-adult return rate (SAR) of Snake River hatchery yearling Chinook (SR $\mathrm{H})$ to (1) mid-Columbia River wild yearling Chinook (MCR W), and (2) mid-Columbia River hatchery yearling Chinook (MCR H). (Only 1 to $2 \%$ of acoustic tagged Snake River smolts were wild, while $18 \%$ of mid-Columbia smolts were wild in 2011.) SR H and MCR H SAR estimates were derived from Comparative Survival Study reports (Tuomikoski et al. 2012), NOAA reports (Faulkner et al. 2012) and Rechisky et al. (2013) and exclude juvenile and adult hydrosystem mortality, i.e. SARs are from Bonneville Dam to return to Bonneville Dam. MCR W SAR only excludes adult hydrosystem mortality; therefore the SR H:MCR W ratio is underestimated. If all delayed mortality of acoustic tagged SIR smolts relative to mid-Columbia IR smolts (in 2011) occurred in the LRE and early marine period, then the expected survival outcomes would lie within this shaded region. 2011 points are jittered to show error bars

ulations in the estuary or early marine period. These results are consistent with our 2006-2009 study, where we found no support for hydrosystem-induced delayed mortality when comparing survival of smolts of similar size and ocean-entry timing from singlesource populations of Snake and mid-Columbia River hatchery origin spring Chinook salmon (Rechisky et al. 2009, 2013).

In addition to testing the hydro-DM hypothesis, we were also able to compare survival of in-river migrating Snake River yearling Chinook to (1) yearling Chinook collected at John Day Dam whose origin was unknown in 2010 and (2) endangered upper Columbia River yearling Chinook in 2011. Survival of the SIR group was comparable to the CIR group in 2010 and the UCIR group in 2011, demonstrating that estuarine and early marine survival was similar for all tagged yearling Chinook irrespective of origin. The comparison between upper Columbia and Snake River-origin Chinook smolts reflects the relative sur- vival of smolts exposed to the 4 federal dams in the Snake River with that of smolts exposed to 3 to 5 public utility district dams in the upper Columbia River. Both groups also migrate through the 4 lower Columbia River dams before reaching the estuary. Because the apparent survival estimates were equivalent between these treatment groups, our study does not indicate that migration through hydro dams in one system is better (or worse) than the other.

We also did not observe strong support for transportation-induced delayed mortality of STR smolts relative to SIR smolts. The lack of an overall effect of transport-DM was not surprising, however, because our sample of smolts from the bypass facilities was comprised primarily of hatchery smolts, and most hatchery populations from the Snake River do not experience decreased transport SARs to the degree that is observed in wild smolts (Tuomikoski et al. 2012). Our results do show that survival of the SIR and STR groups in the lower river and estuary was comparable in both years, and that survival in the plume and coastal ocean fluctuated despite similar body size and release dates. In 2010, STR smolts had lower survival in the plume and higher survival in the coastal ocean relative to SIR smolts, and model selection results and cumulative survival to Lippy Point indicated that transport-DM did not occur. In 2011, survival of the STR group in the plume was somewhat reduced, and survival in the coastal ocean was further reduced relative to the SIR group, but despite reduced survival in these 2 individual migration segments, model selection results did not provide support for transport-DM. Reductions in survival of the STR group in the individual segments in 2011 resulted in a large cumulative survival difference to Lippy Point; however, the error around the 2011 parameter estimates to Lippy Point was large due to reduced sample size at this distant location, particularly for the SIR group (Fig. 7), and thus transport-DM may have occurred. Ideally, the sample size of the SIR group would have been larger in 2011 (only 80 of 580 smolts released below Bonneville Dam were from the Snake River), but because we did not know the genetic origin at 
the time of tagging, we could not control the sample size of the in-river treatment groups.

In our previous study comparing estuarine and early marine survival of spring Chinook smolts from a Snake River hatchery, we found no evidence for transportation-induced delayed mortality (Rechisky et al. 2012). The expected effect (that transported smolts would show reduced survival post-release relative to non-transported smolts) did not occur in the month following ocean entry. In both the present study and our earlier study (Rechisky et al. 2012), fluctuations in plume survival were substantially larger than those occurring in freshwater or in the coastal ocean beyond the plume. Brosnan et al. (2014, this volume) demonstrated that plume survival was primarily related to smolt residence time in the plume, but they also showed that the greater variability in plume survival of groups of transported smolts was likely related to the shorter time period $(\sim 1$ d) that transported smolts entered the plume relative to smolts migrating in-river. Those authors speculated that the compressed entry period may make the survival of transported smolts more variable because there was less opportunity to average out stochastic events affecting survival, such as whether smolts encountered aggregations of predators while migrating through the plume.

It is worth noting that 6.6 and $2.9 \%$ of the PIT tags we implanted in 2010 and 2011, respectively, were recovered in bird colonies. Most were found at East Sand Island near the mouth of the Columbia River (81\% in 2010 and $100 \%$ in 2011). This PIT tag recovery rate is consistent with minimum Chinook predation rates estimated for Caspian terns Hydroprogne caspia (formerly Sterna caspia) and double-crested cormorants Phalacrocorax auritus on East Sand Island (Evans et al. 2012). Given that the tag deposition rate on the island is unknown, that survival upstream of Sand Island was high, and that East Sand Island is in close proximity to the ocean, it is possible that avian predation was responsible for a moderate proportion of the mortality in the plume migration segment.

Several factors should be considered when interpreting our data. First, we assumed that exposure to either dams or transport operations was the primary difference between the treatment groups and the controls. Therefore, Columbia and Snake River populations, which are genetically distinct, could vary in how they respond to the conditions experienced during migration (e.g. temperature, predators, dam bypass). Additionally, there were some differences between our treatment groups in release timing and subsequent ocean entry timing, tagging location and smolt size.

In 2010, we were able to control for tagging location and body size of the SIR and STR groups because they were tagged concurrently at Lower Granite Dam; however, CIR smolts were tagged downstream at John Day Dam and were significantly longer than both the SIR and STR groups at the time of tagging ( $20 \mathrm{~mm}$ on average; Table 1). Additionally, the timing of the CIR releases was chosen to meet the objectives of a separate study, and as a consequence, the CIR smolts reached the ocean about $1 \mathrm{wk}$ before the STR group and 2 wk before the SIR smolts. Estimates of plume survival for the 3 groups were positively correlated with median arrival date at Willapa Bay $\left(R^{2}=0.998\right)$. Given that the survival of the larger CIR smolts was worse in the plume than their smaller SIR counterparts, timing of ocean entry may have been more important for survival than increased body size.

The result that increased body size conferred little to no survival benefit is consistent with our previous findings where we incorporated FL in our Chinook survival models and found either little support for an effect, or variable and contradictory effects (Rechisky \& Welch 2010, Porter et al. 2012). It is possible that size-selective mortality occurs in smolts smaller than $130 \mathrm{~mm}$ FL (Claiborne et al. 2011); however, ocean entry timing may be a more important factor influencing marine survival (e.g. Muir et al. 2006, Scheuerell et al. 2009)

In 2011, we tagged the SIR, MCIR and UCIR groups concurrently at Bonneville Dam, and therefore ocean-entry timing for in-river groups was similar; however, out of necessity, the STR fish were tagged at Lower Granite Dam. This was the first year (since 2006) that the SIR and STR fish were collected at different locations; this was also the first year that we saw some support for transport-DM. Although the SIR smolts were significantly larger than the other treatment groups, the difference was only $\leq 5 \mathrm{~mm}$ on average. As well, ocean-entry dates coincided (median arrival date at Astoria Bridge with 25th to 75th percentile range: SIR = 25 May 2011 [1130 May]; STR = 24 May 2011 [10-26 May]). Therefore, we are more concerned that tagging location may have contributed to the differential survival of STR and SIR groups in the plume and coastal ocean in 2011. Although the juvenile bypasses at these sites do not appear to have differential effects on smolt survival (Buchanan et al. 2011), there was a higher occurrence of pre- and post-tagging mortality at Lower Granite Dam in 2011. Of the 275 fish we col- 
lected, $1 \%$ died prior to sedation, $1 \%$ died during sedation, and $3 \%$ died after tagging and before release. In contrast, at Bonneville Dam only 1 smolt out of 1049 collected $(0.1 \%)$ died after tagging and before release (excluding fish that died from gas bubble trauma prior to release in late May). As stock composition was similar for the SIR and STR groups, and we have never found a measurable tagger effect on survival in our previous studies (Porter et al. 2012), the survival difference may be confounded by capture location.

Lastly, although we collected and tagged yearling Chinook salmon smolts migrating out of the Columbia River Basin over much of the migration season during the 2010-2011 study period (Fig. 4), we did not fully represent the size range of the general population (Fig. 3). The $7 \mathrm{~mm}$ transmitter allowed us to tag a substantial part of the size distribution of hatchery and wild smolts at John Day Dam and Bonneville Dam, but wild smolts at Lower Granite Dam were smaller than the minimum size threshold $(130 \mathrm{~mm}$ FL) we imposed in order to prevent tag burdens from becoming excessive.

One assumption of our work is that equal proportions of each group of smolts swim north after ocean entry and remain on the continental shelf until they are out of our study area. Trudel et al. (2009) compiled more than a decade of juvenile Chinook salmon catch data from multiple at-sea sampling programs ranging from northern California to the Aleutian Islands of Alaska, and established that nearly all (>98\%) mid- and upper Columbia River and Snake River yearling Chinook migrate north and Fisher et al. (2014) found that they do so rapidly. Our telemetry data support this finding. In 2011, we deployed a sub-array at Cascade Head, OR, $130 \mathrm{~km}$ south of the Columbia River mouth to test the assumption that Columbia River Spring Chinook smolts migrate north. Six smolts were detected on the southern subarray compared to 93 which were detected on the northern (Willapa Bay) sub-array. One of the 6 tagged smolts was detected at Cascade Head for 1 wk (30 May to 6 June) and was subsequently detected at Willapa Bay (18 June) and then farther north at Lippy Point (3 July; see visualization at http://vimeo.com/47340003). In our previous study (Rechisky et al. 2012), 2 smolts were detected on the Cascade Head sub-array in 2009, while 136 smolts were detected on the Willapa Bay sub-array. Thus, a very small proportion of smolts may initially migrate south $(3.4 \%$ of fish detected in the ocean in our studies), and we have some evidence that although southward migration may initially occur, smolts do have the capacity to reverse direction and ultimately head north. The 7 smolts that were never detected again either continued to migrate south, or were eaten by a predator before they reached the Willapa Bay sub-array to the north, or migrated around or through the Willapa Bay sub-array undetected. Given the low survival estimates in the plume and coastal ocean, it seems plausible that the 7 initially southern migrating smolts not subsequently detected to the north may have been consumed by predators before reaching the northern arrays.

Second, some smolts may have migrated around the Willapa Bay sub-array, as several smolts were detected on the outer edge of the sub-array (Fig. S2 in the Supplement). Ocean conditions are highly dynamic along the Washington coast near the mouth of the Columbia River (Hickey et al. 2005). This may explain why smolts are widely distributed across the shelf at Willapa Bay. However, because smolts appeared to be confined to the shelf farther north at Lippy Point (Fig. S3 in the Supplement), our survival models should account for any undetected or offshelf migrant smolts at Willapa Bay and thus the survival estimates would not be affected.

If these limitations differentially affect survival, the net effect would have to be large enough to mask an up to 2-fold difference in apparent survival to Lippy Point for SIR smolts relative to the MCIR smolts (Fig. 9), assuming that all delayed mortality caused by prior hydrosystem experience is expressed by the end of the first month at sea. As we found no support for hydro-DM within the co-migration corridor, we conclude that the observed survival difference seen in the adult return rates likely develops in the ocean farther north or that delayed mortality is greatly delayed.

Numerous studies are beginning to shed light on the ocean distribution and migration behaviour of Chinook salmon in the North Pacific Ocean (e.g. Fisher et al. 2007, Trudel et al. 2009, Peterson et al. 2010, Weitkamp 2010, Tucker et al. 2011, Larson et al. 2013), and some specific ocean distribution information is now available for the genetically distinct population groupings identified in this study. MidColumbia, upper Columbia and Snake River yearling Chinook migrate quickly into coastal waters of British Columbia and Southeast Alaska during summer, but are rare in the fall, indicating that they migrate through those areas before leaving the shelf (Trudel et al. 2009, Tucker et al. 2011). Since we did not detect acoustic tagged smolts from the mid and upper Columbia River populations on our sub-array in southeast Alaska in 2010 (the Alaska sub-array 
was not deployed in 2011), and we did not detect Yakima River hatchery smolts (also from the midColumbia River) on that sub-array in our previous study (Rechisky et al. 2013), it is possible that midColumbia populations may leave the shelf at a different time or location and have different subsequent ocean distributions which may result in consistently different adult return rates. Larson et al. (2013) reported that immature Chinook salmon from the coastal US (WA, OR, CA) are found on the eastern Bering Sea shelf during summer and fall. Although fine-scale stock resolution was not reported, it is plausible that specific populations of Columbia River Basin Chinook may enter the Bering Sea, and that there may be a common ocean process influencing fitness in that region.

Our results demonstrate that mortality processes affecting Snake River Chinook salmon fitness may occur later in the marine life history, which supports the idea that the critical period may not be only limited to high predation rates soon after ocean entry (Beamish \& Mahnken 2001). It remains unclear whether smaller, wild Snake River smolts have survival comparable to the smolts reported here, although there is evidence that hatchery and wild smolts respond similarly to ocean conditions (Daly et al. 2012) and have similar ocean distributions (Tucker et al. 2011). Recent advances in transmitter miniaturization mean that it is now feasible to repeat these experimental tests using wild smolts, which would address perhaps the greatest remaining uncertainty concerning the potential role of dam-induced and transport-induced mortality on fitness.

Acknowledgements. This work is a contribution to the Census of Marine Life. We especially thank M. Jacobs and P. Winchell for managing tagging and array operations; P. Callow, P. Pawlik, M. Wilberding, I. Brosnan, A. Collins and J. Payne for field assistance; the many vessel captains who worked with us to maintain the acoustic array; and D. Ballinger, G. Kovalchuk, S. Rapp and staff at the Smolt Monitoring Program. Funding for this work was provided by the US Department of Energy, BPA, Project No. 2003-114-00. Additional sub-arrays (JDF, NSG, QCS) in Fig. 1 were owned by the Pacific Ocean Shelf Tracking project (POST) and funded by the Gordon \& Betty Moore and Alfred P. Sloan Foundations.

\section{LITERATURE CITED}

ADF\&G Chinook Salmon Research Team (2013) Chinook salmon stock assessment and research plan, 2013. Special Publication No. 13-01. Alaska Department of Fish and Game, Anchorage, AK

Anderson EC (2010) Computational algorithms and userfriendly software for parentage-based tagging of Pacific salmonids. A final report to the Pacific Salmon Commis- sion's Chinook Technical Committee (US Section), Vancouver, BC

Anderson JJ, Ham KD, Gosselin JL (2011) Snake River Basin differential delayed mortality synthesis. Report No. PNWD-4283. Report to the US Army Corps of Engineers, Walla Walla, WA

Beamish R, Mahnken C (2001) A critical size and period hypothesis to explain natural regulation of salmon abundance and the linkage to climate and climate change. Prog Oceanogr 49:423-437

Bi H, Ruppel RE, Peterson WT (2007) Modeling the pelagic habitat of salmon off the Pacific Northwest (USA) coast using logistic regression. Mar Ecol Prog Ser 336:249-265

*Bouck GR (1980) Etiology of gas bubble disease. Trans Am Fish Soc 109:703-707

Brosnan IG, Welch DW, Rechisky EL, Porter AD (2014) Evaluating the influence of environmental factors on yearling Chinook salmon survival in the Columbia River plume (USA). Mar Ecol Prog Ser 496:181-196

Brown RS, Geist DR, Deters KA, Grassell A (2006) Effects of surgically implanted acoustic transmitters $>2 \%$ of body mass on the swimming performance, survival and growth of juvenile sockeye and Chinook salmon. J Fish Biol 69:1626-1638

* Brown RS, Harnish RA, Carter KM, Boyd JW, Deters KA, Eppard MB (2010) An evaluation of the maximum tag burden for implantation of acoustic transmitters in juvenile Chinook salmon. N Am J Fish Manag 30:499-505

Buchanan RA, Skalski JR, Townsend RL, Ham KD (2011) The effect of bypass passage on adult returns of salmon and steelhead: an analysis of PIT-tag data using the program ROSTER. Report No. PNWD-4241. Report to the US Army Corps of Engineers, Walla Walla, WA

* Budy P, Thiede GP, Bouwes N, Petrosky CE, Schaller H (2002) Evidence linking delayed mortality of Snake River salmon to their earlier hydrosystem experience. N Am J Fish Manag 22:35-51

* Burke BJ, Peterson WT, Beckman BR, Morgan C, Daly EA, Litz M (2013) Multivariate models of adult Pacific salmon returns. PLoS ONE 8:e54134

Burnham KP, Anderson DR (2002) Model selection and multimodel inference: a practical information-theoretic approach. Springer-Verlag, New York, NY

Chapman DW (1986) Salmon and steelhead abundance in the Columbia River in the 19th-century. Trans Am Fish Soc 115:662-670

* Claiborne AM, Fisher JP, Hayes SA, Emmett RL (2011) Size at release, size-selective mortality, and age of maturity of Willamette River Hatchery yearling Chinook salmon. Trans Am Fish Soc 140:1135-1144

* Clemens BJ, Clements SP, Karnowski MD, Jepsen DB, Gitelman AI, Schreck CB (2009) Effects of transportation and other factors on survival estimates of juvenile salmonids in the unimpounded lower Columbia River. Trans Am Fish Soc 138:169-188

* Congleton JL, LaVoie WJ, Schreck CB, Davis LE (2000) Stress indices in migrating juvenile Chinook salmon and steelhead of wild and hatchery origin before and after barge transportation. Trans Am Fish Soc 129:946-961

* Connor W, Sneva J, Tiffan K, Steinhorst R, Ross D (2005) Two alternative juvenile life history types for fall Chinook salmon in the Snake River basin. Trans Am Fish Soc 134:291-304

Cormack RM (1964) Estimates of survival from the sighting of marked animals. Biometrika 51:429-438

Cox DR, Snell EJ (1989) Analysis of binary data. Chapman \& Hall, New York, NY 
Daly EA, Brodeur RD, Fisher JP, Weitkamp LA, Teel DJ, Beckman BR (2012) Spatial and trophic overlap of marked and unmarked Columbia River Basin spring Chinook salmon during early marine residence with implications for competition between hatchery and naturally produced fish. Environ Biol Fishes 94:117-134

Deriso RB, Marmorek DR, Parnell IJ (2001) Retrospective patterns of differential mortality and common yeareffects experienced by spring and summer Chinook salmon (Oncorhynchus tshawytscha) of the Columbia River. Can J Fish Aquat Sci 58:2419-2430

Evans AF, Hostetter NJ, Roby DD, Collis K and others (2012) Systemwide evaluation of avian predation on juvenile salmonids from the Columbia River based on recoveries of passive integrated transponder tags. Trans Am Fish Soc 141:975-989

Faulkner JR, Smith SG, Muir WD, Marsh DM, Zabel RW (2011) Survival estimates for the passage of springmigrating juvenile salmonids through Snake and Columbia River dams and reservoirs, 2011. Project No. 1993029-00. Report to the Bonneville Power Administration, Portland, OR

Faulkner JR, Smith SG, Marsh DM, Zabel RW (2012) Survival estimates for the passage of spring-migrating juvenile salmonids through Snake and Columbia River dams and reservoirs, 2012. Project No. 1993-029-00. Report to the Bonneville Power Administration, Portland, OR

Ferguson JW (2010) Estimation of percentages for listed Pacific salmon and steelhead smolts arriving at various locations in the Columbia River Basin in 2010. November 9, 2010 Memorandum to James H. Lecky. US Dept. of Commerce, National Oceanic and Atmospheric Administration, National Marine Fisheries Service, Northwest Fisheries Science Center, Seattle, WA

Fisher JP, Pearcy WG (1995) Distribution, migration, and growth of juvenile Chinook salmon, Oncorhynchus tshawytscha, off Oregon and Washington. Fish Bull 93: 274-289

Fisher J, Trudel M, Ammann A, Orsi JA and others (2007) Comparisons of the coastal distributions and abundances of juvenile Pacific salmon from central California to the northern Gulf of Alaska. Am Fish Soc Symp 57:31-80

Fisher JP, Weitkamp LA, Teel JD, Hinton SA and others (2014) Early ocean dispersal patterns of Columbia River Chinook and coho salmon. Trans Am Fish Soc 143: $252-272$

Haeseker SL, McCann JA, Tuomikoski J, Chockley B (2012) Assessing freshwater and marine environmental influences on life-stage-specific survival rates of Snake River spring-summer Chinook salmon and steelhead. Trans Am Fish Soc 141:121-138

Hare SR, Mantua NJ, Francis RC (1999) Inverse production regimes: Alaska and West Coast Pacific salmon. Fisheries 24:6-14

*Harnish RA, Johnson GE, McMichael GA, Hughes MS, Ebberts BD (2012) Effect of migration pathway on travel time and survival of acoustic-tagged juvenile salmonids in the Columbia River estuary. Trans Am Fish Soc 141: 507-519

Healey MC (1991) Life history of Chinook salmon. In: Groot C, Margolis L (eds) Pacific salmon life histories. UBC Press, Vancouver, BC, p 313-393

Hess JE, Campbell NR, Matala AP, Narum SR (2012) Genetic assessment of Columbia River stocks. Project No. 2008-907-00. Report to the Bonneville Power Administration, Portland, OR
Hickey B, Geier S, Kachel N, MacFadyen A (2005) A bidirectional river plume: the Columbia in summer. Cont Shelf Res 25:1631-1656

Joint Columbia River Management Staff (2012) 2012 Joint staff report: stock status and fisheries for spring Chinook, summer Chinook, sockeye, steelhead, and other species, and miscellaneous regulations. Oregon Department of Fish \& Wildlife and Washington Department of Fish \& Wildlife, Olympia, WA

Jolly GM (1965) Explicit estimates from capture-recapture data with both death and immigration-stochastic model. Biometrika 52:225-247

Kareiva P, Marvier M, McClure M (2000) Recovery and management options for spring/summer Chinook salmon in the Columbia River Basin. Science 290:977-979

Keefer ML, Caudill CC, Peery CA, Lee SR (2008) Transporting juvenile salmonids around dams impairs adult migration. Ecol Appl 18:1888-1900

Larson WA, Utter FM, Myers KW, Templin WD and others (2013) Single-nucleotide polymorphisms reveal distribution and migration of Chinook salmon (Oncorhynchus tshawytscha) in the Bering Sea and North Pacific Ocean. Can J Fish Aquat Sci 70:128-141

* Levin PS, Zabel RW, Williams JG (2001) The road to extinction is paved with good intentions: negative association of fish hatcheries with threatened salmon. Proc R Soc Lond B Biol Sci 268:1153-1158

Lindley ST, Grimes CB, Mohr MS, Peterson W and others (2009) What caused the Sacramento River fall Chinook stock collapse? NOAA Tech Memo NMFS-SWFSC-447. US Dept. of Commerce, National Oceanic and Atmospheric Administration, National Marine Fisheries Service, Silver Spring, MD

KMantua NJ, Hare SR, Zhang Y, Wallace JM, Francis RC (1997) A Pacific interdecadal climate oscillation with impacts on salmon production. Bull Am Meteorol Soc 78: 1069-1079

* McMichael GA, Eppard MB, Carlson TJ, Carter JA and others (2010) The juvenile salmon acoustic telemetry system: a new tool. Fisheries 35:9-22

McMichael GA, Skalski JR, Deters KA (2011) Survival of juvenile Chinook salmon during barge transport. N Am J Fish Manag 31:1187-1196

Mesa MG, Weiland LK, Maule AG (2000) Progression and severity of gas bubble trauma in juvenile salmonids. Trans Am Fish Soc 129:174-185

* Miller DR, Williams JG, Sims CW (1983) Distribution, abundance and growth of juvenile salmonids off the coast of Oregon and Washington, summer 1980. Fish Res 2:1-17

*Muir WD, Marsh DM, Sandford BP, Smith SG, Williams JG (2006) Post-hydropower system delayed mortality of transported Snake River stream-type Chinook salmon: unraveling the mystery. Trans Am Fish Soc 135: 1523-1534

Narum SR, Hess JE, Matala AP (2010) Examining genetic lineages of Chinook salmon in the Columbia River basin. Trans Am Fish Soc 139:1465-1477

National Research Council (1996) Upstream: salmon and society in the Pacific Northwest. National Academy Press, Washington, DC

NOAA Fisheries Service (2013) Forecast of adult returns for coho and Chinook salmon. Available at www.nwfsc. noaa.gov/research/divisions/fed/oeip/g-forecast.cfm (accessed 3 April 2013)

Northwest Power and Conservation Council (2009) Columbia River Basin Fish and Wildlife Program. Council Doc- 
ument 2009-09. Northwest Power and Conservation Council, Portland, OR

Paulsen CM, Fisher TR (2001) Statistical relationship between parr-to-smolt survival of Snake River springsummer Chinook salmon and indices of land use. Trans Am Fish Soc 130:347-358

Peterson WT, Morgan CA, Fisher JP, Casillas E (2010) Ocean distribution and habitat associations of yearling coho (Oncorhynchus kisutch) and Chinook (O. tshawytscha) salmon in the northern California Current. Fish Oceanogr 19:508-525

Porter AP, Welch DW, Rechisky EL, Jacobs MC, Winchell PM, Day J (2012) Marine and freshwater measurement of delayed and differential-delayed mortality of Columbia and Snake River yearling Chinook smolts using a continental-scale acoustic telemetry array, 2011. Project No. 2003-114-00. Report to the Bonneville Power Administration, Portland, OR

Raymond HL (1979) Effects of dams and impoundments on migrations of juvenile Chinook salmon and steelhead from the Snake River, 1966 to 1975. Trans Am Fish Soc 108:505-529

Raymond HL (1988) Effects of hydroelectric development and fisheries enhancement on spring and summer Chinook salmon and steelhead in the Columbia River Basin. N Am J Fish Manag 8:1-24

Rechisky EL, Welch DW (2010) Surgical implantation of acoustic tags: influence of tag loss and tag-induced mortality on free-ranging and hatchery-held spring Chinook (O. tshawytscha) smolts. In: Wolf KS, O'Neal JS (eds) PNAMP special publication. Tagging, telemetry and marking measures for monitoring fish populations. A compendium of new and recent science for use in informing technique and decision modalities. Pacific Northwest Aquatic Monitoring Partnership Special Publication 2010-002. PNAMP, Duvall, WA, p 71-96. Available at www.pnamp.org/document/3635

Rechisky EL, Welch DW, Porter AD, Jacobs MC, Ladouceur A (2009) Experimental measurement of hydrosysteminduced delayed mortality in juvenile Columbia River spring Chinook salmon using a large-scale acoustic array. Can J Fish Aquat Sci 66:1019-1024

Rechisky EL, Welch DW, Porter AD, Jacobs-Scott MC, Winchell PM, McKern JL (2012) Estuarine and earlymarine survival of transported and in-river migrant Snake River spring Chinook salmon smolts. Sci Rep 2: 448

Rechisky EL, Welch DW, Porter AD, Jacobs-Scott MC, Winchell PM (2013) Influence of multiple dam passage on survival of juvenile Chinook salmon in the Columbia River estuary and coastal ocean. Proc Natl Acad Sci USA 110:6883-6888

Schaller HA, Petrosky CE (2007) Assessing hydrosystem influence on delayed mortality of Snake River streamtype Chinook salmon. N Am J Fish Manag 27:810-824

Schaller HA, Petrosky CE, Langness OP (1999) Contrasting patterns of productivity and survival rates for streamtype Chinook salmon (Oncorhynchus tshawytscha) populations of the Snake and Columbia rivers. Can J Fish Aquat Sci 56:1031-1045

Scheuerell MD, Zabel RW, Sandford BP (2009) Relating juvenile migration timing and survival to adulthood in two species of threatened Pacific salmon (Oncorhynchus spp.). J Appl Ecol 46:983-990

Schreck CB, Stahl TP, Davis LE, Roby DD, Clemens BJ (2006) Mortality estimates of juvenile spring-summer
Chinook salmon in the lower Columbia River and estuary, 1992-1998: evidence for delayed mortality? Trans Am Fish Soc 135:457-475

Seber GAF (1965) A note on the multiple recapture census. Biometrika 52:249-259

Smith SG, Marsh DM, Emmett RL, Muir WD, Zabel RW (2013) A study to determine seasonal effects of transporting fish from the Snake River to optimize a transportation strategy. National Marine Fisheries Service, Northwest Fisheries Science Center, Research Report to US Army Corps of Engineers, Walla Walla, WA

Steele CA, Campbell MR, Ackerman M, McCane J, Hess MA, Campbell N, Narum SR (2011) Parentage based tagging of Snake River hatchery steelhead and Chinook salmon. Report No. 2010-031-00. Report to the Bonneville Power Administration, Portland, OR

Steele CA, Anderson EC, Ackerman MW, Hess MA, Campbell NR, Narum SR, Campbell MR (2013) A validation of parentage-based tagging for hatchery steelhead in the Snake River Basin. Can J Fish Aquat Sci 70:1046-1054

Trudel M, Fisher J, Orsi JA, Morris JFT and others (2009) Distribution and migration of juvenile Chinook salmon derived from coded wire tag recoveries along the continental shelf of western North America. Trans Am Fish Soc 138:1369-1391

Tucker S, Trudel M, Welch DW, Candy JR and others (2011) Life history and seasonal stock-specific ocean migration of juvenile Chinook salmon. Trans Am Fish Soc 140: $1101-1119$

Tuomikoski J, McCann J, Chockley B, Schaller H and others (2012) Comparative survival study (CSS) of PIT-tagged spring/summer Chinook and PIT-tagged summer steelhead, 2012 Annual Report. Project No. 1993-020-00. Report to the Bonneville Power Administration, Portland, OR

*Van Gaest AL, Dietrich JP, Thompson DE, Boylen DA and others (2011) Survey of pathogens in hatchery Chinook salmon with different out-migration histories through the Snake and Columbia rivers. J Aquat Anim Health 23: 62-77

WWagenmakers EJ, Farrell S (2004) AIC model selection using Akaike weights. Psychon Bull Rev 11:192-196

WWard DL, Boyce RR, Young FR, Olney FE (1997) A review and assessment of transportation studies for juvenile Chinook salmon in the Snake River. N Am J Fish Manag 17:652-662

*Weitkamp LA (2010) Marine distributions of Chinook salmon from the west coast of North America determined by coded wire tag recoveries. Trans Am Fish Soc 139: $147-170$

*Welch DW, Melnychuk MC, Payne JC, Rechisky EL and others (2011) In situ measurement of coastal ocean movements and survival of juvenile Pacific salmon. Proc Natl Acad Sci USA 108:8708-8713

White GC, Burnham KP (1999) Program MARK: survival estimation from populations of marked animals. Bird Study 46(Suppl 001):S120-S139

Williams JG, Smith SG, Zabel RW, Muir WD and others (2005) Effects of the federal Columbia River power system on salmon populations. NOAA Tech Memo NMFS-NWFSC-63. US Dept. of Commerce, National Oceanographic and Atmospheric Administration, National Marine Fisheries Service, Silver Spring, MD

*Wilson PH (2003) Using population projection matrices to evaluate recovery strategies for Snake River spring and summer Chinook salmon. Conserv Biol 17:782-794 